\title{
Surgical resection of hepatic metastases from colorectal cancer: A systematic review of published studies
}

\author{
PC Simmonds', JN Primrose ${ }^{*, 2}$, JL Colquitt', OJ Garden ${ }^{3}$, GJ Poston ${ }^{4}$ and M Rees ${ }^{5}$ \\ 'Cancer Research UK Clinical Centre, MP824, Southampton General Hospital, Tremona Road, Southampton SO I 6 6YD, UK; '2 University Surgery, F Level \\ Centre Block (MP8 I6), Southampton General Hospital, Southampton SO I 6 6YD, UK; ${ }^{3}$ Department of Clinical and Surgical Sciences, Royal Infirmary of \\ Edinburgh, 51 Little France Crescent, Old Dalkeith Road, Edinburgh, Scotland EHI 6 4SA, UK; ${ }^{4}$ Department of Surgery, University Hospital Aintree, \\ Longmoor Lane, Liverpool L9 7AL, UK; ${ }^{5}$ Hepatobiliary Surgery Unit, North Hampshire Hospital, Aldermaston Road, Basingstoke RG24 9NA, UK
}

No consensus on the indications for surgical resection of colorectal liver metastases exists. This systematic review has been undertaken to assess the published evidence for its efficacy and safety and to identify prognostic factors. Studies were identified by computerised and hand searches of the literature, scanning references and contacting investigators. The outcome measures were overall survival, disease-free survival, postoperative morbidity and mortality, quality of life and cost effectiveness, and a qualitative summary of the trends across all studies was produced. Only 30 of 529 independent studies met all the eligibility criteria for the review, and data on 30-day mortality and morbidity only were included from a further nine studies. The best available evidence came from prospective case series, but only two studies reported outcomes for all patients undergoing surgery. The remainder reported outcomes for selected groups of patients: those undergoing hepatic resection or those undergoing curative resection. Postoperative mortality rates were generally low (median $2.8 \%$ ). The majority of studies described only serious postoperative morbidity, the most common being bile leak and associated perihepatic abscess. Approximately 30\% of patients remained alive 5 years after resection and around two-thirds of these are disease free. The quality of the majority of published papers was poor and ascertaining the benefits of surgical resection of colorectal hepatic metastases is difficult in the absence of randomised trials. However, it is clear that there is group of patients with liver metastases who may become long-term disease- free survivors following hepatic resection. Such survival is rare in apparently comparable patients who do not have surgical treatment. Further work is needed to more accurately define this group of patients and to determine whether the addition of adjuvant treatments results in improved survival.

British Journal of Cancer (2006) 94, 982-999. doi: I0.1038/sj.bjc.6603033 www.bjcancer.com

Published online 14 March 2006

(C) 2006 Cancer Research UK

Keywords: colorectal liver metastases; surgery; systematic review; survival; morbidity

Colorectal cancer is the third most common cause of cancer death in the UK (Cancer Research UK Information Resource Centre, 2003). Surgery is the treatment of choice for patients with localised disease but over half of all patients will develop metastases. The liver is often the first site of metastatic disease and may be the only site of spread in as many as $30-40 \%$ of patients with advanced disease (Weiss et al, 1986; Hugh et al, 1997a).

It has been postulated that because haematogenous spread usually occurs in a stepwise fashion, initially to the liver, with subsequent intrahepatic spread via the portal vein and further spread to the systemic circulation, surgical resection of isolated hepatic metastases from colorectal cancer may be curative.

The natural history of metastatic colorectal cancer is variable, with a median survival without treatment of only 8 months (Seymour et al, 1997; Simmonds, 2000). Patients with isolated hepatic metastases have a better prognosis than those with more

*Correspondence: Professor JN Primrose;

E-mail: j.n.primrose@soton.ac.uk

Received 2 November 2005; revised 7 February 2006; accepted 7 February 2006; published online 14 March 2006 extensive metastatic disease (Goslin et al, 1982; Lahr et al, 1983; Stangl et al, 1994; Rougier et al, 1995) suggesting biological differences in the two settings (Goslin et al, 1982; Lahr et al, 1983; Stangl et al, 1994; Rougier et al, 1995). However, few patients with limited liver-only metastases survive for 5 years (Goslin et al, 1982; Stangl et al, 1994).

A variety of therapeutic approaches have been used in the treatment of metastatic colorectal cancer including surgery, chemotherapy, radiofrequency ablation, cryotherapy or some combination of these (Primrose, 2002). Around 20-30\% of patients with liver-only metastases are potentially resectable (Nordlinger et al, 1994; Stangl et al, 1994; Jeffery et al, 2002). The selection criteria for surgery are usually controlled primary tumour, no extra hepatic metastases and that resection is technically feasible with tumour-free margins (Hugh et al, 1997b). A small proportion of patients with completely resectable extrahepatic disease may become long-term survivors (Scheele et al, 1995). Chemotherapy used alone is palliative but may prolong the survival of patients with unresectable disease (de Gramont et al, 2000; Douillard et al, 2000; Saltz et al, 2000; Simmonds, 2000). Used in combination with surgery it may prolong the time to recurrence after resection of hepatic 
metastases (Kemeny et al, 2002) or downsize to resectability patients previously judged inoperable (Giacchetti et al, 1999). The role of other treatments is poorly defined (Armstrong et al, 1994; Donovan, 1995; Adam et al, 1997; de Baere et al, 1999; Primrose, 2002).

Although there are a large number of published studies reporting the results of surgical resection of hepatic metastases from colorectal cancer, the effectiveness and cost effectiveness of such surgery remains unclear. This systematic review has been undertaken to assess the published evidence for the efficacy and safety of this intervention and, by examining potential prognostic factors, identify patients who may either benefit from surgery or in whom such intervention is inappropriate.

\section{METHODS}

\section{Criteria for selecting studies}

As randomised trials comparing surgical resection $v s$ no surgery have never been conducted, we have attempted to identify all relevant prospective and retrospective series reporting the outcomes of surgical resection with curative intent of colorectal hepatic metastases. Patients undergoing repeat hepatic resection were also included. In order to ensure that the surgical series reviewed reflected the outcomes for patients treated with modern surgical, anaesthetic and supportive care techniques, we have restricted our qualitative analysis to surgical series published after 1980 reporting the outcomes of at least 100 patients. Studies were required to follow patients for at least 30 days for inclusion of data on postoperative morbidity and mortality, and for a median of at least 24 months for inclusion of survival data. No language restriction was applied on searching. All eligible European language studies were translated, but retrospective non-European articles were not.

The outcome measures were overall survival ( 1 year $/ 3$ year $/ 5$ year), disease-free survival (1 year/3 year/5 year), operative and postoperative morbidity, operative and postoperative mortality, quality of life and cost effectiveness.

\section{Search strategy}

We searched the following electronic databases: Cochrane Controlled Trials Register, Medline, Embase, Cancerlit, Science Citation Index, Edina Biosis, CINAHL and NHS Economic Evaluation Database. Both medical subject heading and free text searching were used to improve the sensitivity of the search. The search strategy was piloted and modified to improve the hit rate, and the sensitivity of the search strategy was tested by hand searching three journals in which a high proportion of identified studies had been published (Cancer, British Journal of Surgery, and Diseases of the Colon and Rectum, 1998-1999). All relevant studies had been identified, confirming that the search was comprehensive. Searching took place between May 2000 and October 2000. The full search strategy is available from the authors on request.

The following registers were searched for details of ongoing and unpublished studies: National Research Register, Current Controlled Trials, MRC Funded Research database, UKCCCR trials register, Centre Watch Clinical Trials listing, Physician Data Query (USA), National Institutes of Health Clinical Trials (USA), National Health and Medical Research Council (Australia), Trial Amnesty on the Cochrane library, System for Information on Grey Literature in Europe (SIGLE). Investigators of eligible prospective studies and large surgical centres were contacted to find further published, unpublished or ongoing studies, and the reference lists of review articles on this subject and all eligible studies were examined. In order to identify studies that had not been indexed in the above sources, the Proceedings of the American Society of Clinical Oncology (1982-2000) were hand searched.

\section{Review procedures and analysis}

All relevant studies were assessed according to the above inclusion criteria using a standard checklist performed independently by two reviewers (one clinical and one non-clinical) and agreement on eligibility was reached. Investigators were contacted for further information where eligibility could not be determined from the published study. Data were extracted from published papers by one reviewer using a standard data extraction sheet and then verified independently by a second reviewer. Data extracted included demographic characteristics of patients, preoperative comorbidities, details of the primary tumour, details of hepatic and extrahepatic metastases, type of resection, nonsurgical therapy and outcomes. When a study had generated multiple publications, the most recent was used to extract data on relevant outcome variables. Earlier publications were used to provide information on baseline characteristics or methodology where necessary. Validity was assessed independently by two reviewers using a standard critical appraisal checklist. For the purposes of this review, items relevant to the assessment of uncontrolled surgical case series were combined from two checklists (Cowley, 1995; Downs and Black, 1998). The checklist was piloted by two reviewers and assessed quality of reporting and internal and external validity. An index of inter-rater agreement was calculated using the Kappa statistic. As all of the eligible published studies were either prospective or retrospective case series, a qualitative summary was produced to identify and describe trends across all studies.

\section{RESULTS}

\section{Description of studies identified}

Of 529 studies identified by our initial search strategy, 470 were not included in the review, often for more than one reason: 409 (77\%) reported less than 100 patients, the median follow-up was less than 24 months in 45 (9\%) and unclear in 345 (65\%) studies. Other reasons for exclusion were combined data from colorectal and non-colorectal liver metastases (38/529) and lack of mortality and survival data (21/529). The eligibility of 19 publications was unclear, but as these were updated elsewhere the older reports were excluded, and 15 studies were not included because their eligibility remained unclear despite seeking further details from the authors of the original report. A list of excluded studies with reasons for exclusion is available on request from the authors.

Forty-nine published and unpublished studies met all the inclusion criteria, including multiple publications presenting updated information or data on different aspects of the same patient population, providing 30 independent eligible studies. Eighteen of these were single publications (Savage and Malt, 1992; Sugihara et al, 1993; Donato et al, 1994; Doci et al, 1995; Fernandez-Trigo et al, 1995; Fuhrman et al, 1995; Beckurts et al, 1997; Rees et al, 1997; Cady et al, 1998; Ohlsson et al, 1998; Riesener et al, 1998; Bradley et al, 1999; Harmon et al, 1999; Harms et al, 1999; Kemeny et al, 1999a; Bolton and Fuhrman, 2000; Okano et al, 2000; Moroz et al, 2002) and in a further 12 cases the data was obtained from multiple publications (Hughes et al, 1988, 1989; Hohenberger et al, 1990, 1994; Scheele et al, 1990, 1991, 1995, 1996; Steele Jr et al, 1991, 1995; Rosen et al, 1992; Gayowski et al, 1994; Stangl et al, 1994; Fong et al, 1995, 1997, 1999; Leslie et al, 1995; Jamison et al, 1996, 1997; Jenkins et al, 1997; Bakalakos et al, 1998a, b; Iwatsuki et al, 1999; Minagawa et al, 1999; Ambiru et al, 1999a; Kemeny et al, 1999b, c; Brand et al, 2000; DeMatteo et al, 2000; Minagawa et al, 2000). In addition, data on 30-day mortality and morbidity were included from a further nine studies (one with two publications) in which survival data was excluded owing to insufficient or unclear follow up (Minton and Abou-Issa, 1990; Fegiz et al, 1991; Nordlinger et al, 1992; van Ooijen et al, 1992; Wade et al, 1996; Lorenz et al, 1997, 1998; Nadig et al, 1997; Taylor 
et al, 1997; Figueras et al, 2001). Details of all studies are tabulated in Appendix A.

Just two studies included all patients presenting with colorectal liver metastases (Scheele et al, 1990, 1991, 1995, 1996; Stangl et al, 1994; Harms et al, 1999) and only three studies presented data on all patients undergoing surgery (radical, nonradical and laparotomy) (Steele Jr et al, 1991, 1995; Fuhrman et al, 1995; Bakalakos et al, 1998a). The majority (27) of studies presented data on resected patients, but while some studies distinguished between R0 resections (no residual disease, histologically clear margins), R1 (histologically involved margins) and $\mathrm{R} 2$ resections (macroscopic residual disease), in many this was unclear. Six studies included only a select group of patients undergoing radical resection, and one study included patients undergoing repeat resection only.

Eleven studies were conducted prospectively, three of which were randomised controlled trials comparing surgery alone with surgery plus chemotherapy (Lorenz et al, 1998; Kemeny et al, 1999a) or comparing two adjuvant chemotherapy regimes (Kemeny et al, 1999c). Twenty-five studies were retrospective and the design of three studies was unclear. Twenty-six studies were conducted in single centres, 11 were multicentre studies and two were undertaken by two centres.

No data was found on comorbidity, quality of life, or cost effectiveness of liver resection.

\section{Methodological quality of included studies}

There was consistency in validity appraisal between the two reviewers, as indicated by a Kappa statistic of 0.79 . The 16-point validity scale was completed for all studies, including one study that was published in abstract form only (Kemeny et al, 1999a) (Appendix B). Total scores ranged from 2 to 14 (mean 8.7, median 9).

The quality of reporting was poor in many studies. Eligibility criteria for surgery or inclusion criteria in the study were not reported by $12(31 \%)$ studies. The distribution of principal confounders, such as synchronous or metachronous metastases and curative intent of surgery were not reported by almost a third of studies. Basic demographic information such as mean age and sex distribution was also often missing. Patients were thought to be representative in only a minority of studies (mostly highly selected), and similarly the treatment centres were considered to be unrepresentative (highly specialised).

The primary end points of mortality and survival were not clearly defined in 33 and $74 \%$ of studies, respectively; therefore, the comparability of results between studies is unclear. Postoperative mortality was excluded from survival analysis in $21 \%$ studies, and patients lost to follow-up were not reported or not included in the appropriate analysis by over half of the studies. Median length of follow-up was not reported by $31 \%$ of studies. The outcome of patients receiving surgery alone was reported by just $12(31 \%)$ studies. In $10(26 \%)$ studies patients receiving additional therapies such as adjuvant chemotherapy were not analysed separately. Further, the use of additional therapies was not stated in 17 (44\%) studies.

\section{Postoperative mortality}

Death within 30 days of hepatic resection was reported by 24 studies, ranging from 0 to $6.6 \%$ of patients (median 2.8\%). A further nine studies reported perioperative mortality within an undefined time period (1.3-4.6\%, median 3.6\%), and two studies reported 60 -day mortality $(3.4-5.5 \%)$. Mortality was not reported by four studies. Cause of death was reported by 15 studies for a total of 103 patients (Table 1), including two studies that reported deaths from surgical complications occurring within 90 days (Iwatsuki et al, 1999) and 128 days (Scheele et al, 1996).
Table I Fatal complications

\begin{tabular}{|c|c|c|c|}
\hline & $\begin{array}{l}\text { No. of } \\
\text { studies }\end{array}$ & $\begin{array}{c}\text { No. of } \\
\text { patients }\end{array}$ & $\begin{array}{c}\% \text { of } \\
\text { reported } \\
\text { fatalities } \\
(n=103)\end{array}$ \\
\hline Bile leak & 4 & 6 & 5.8 \\
\hline Perihepatic abscess & 2 & 3 & 2.9 \\
\hline Hepatic failure & 10 & 19 & 18.4 \\
\hline Renal failure & 4 & 4 & 3.9 \\
\hline Generalised sepsis & 8 & 17 & 16.5 \\
\hline Peritonitis & 2 & 3 & 2.9 \\
\hline Gl bleed & 3 & 3 & 2.9 \\
\hline Deep vein thrombosis & 1 & 1 & 1.0 \\
\hline Pulmonary embolism & 4 & 7 & 6.8 \\
\hline Myocardial infarction & 3 & 3 & 2.9 \\
\hline Cardiac failure & 6 & 12 & 11.7 \\
\hline Arrhythmia & I & 3 & 2.9 \\
\hline Pneumonia & 2 & 2 & 1.9 \\
\hline Cerebrovascular accident & 2 & 3 & 2.9 \\
\hline Urinary tract infection & 1 & । & 1.0 \\
\hline Postoperative haemorrhage & 8 & 18 & 17.5 \\
\hline Adult respiratory distress syndrome & 2 & 4 & 3.9 \\
\hline Multisystem organ failure & 2 & 7 & 6.8 \\
\hline Anastomotic leak/insufficiency & 2 & 6 & 5.8 \\
\hline Other & 8 & 14 & 13.6 \\
\hline
\end{tabular}

NB patients may have had more than one cause of death

\section{Postoperative morbidity}

Perioperative complications, including indicators of morbidity such as length of hospital stay, were reported by 29 studies. However, some studies reported fatal complications only (van Ooijen et al, 1992; Scheele et al, 1996; Lorenz et al, 1998; Bolton and Fuhrman, 2000; Moroz et al, 2002), length of hospital stay only (Hohenberger et al, 1994; Fuhrman et al, 1995), blood transfusions only (Jamison et al, 1997) or simply reported the number of patients with nonspecified complications (van Ooijen et al, 1992; Fernandez-Trigo et al, 1995; Scheele et al, 1996; Jenkins et al, 1997; Taylor et al, 1997; Bakalakos et al, 1998a; Fong et al, 1999; Figueras et al, 2001).

The number of studies reporting each complication and the number of patients with the complication is presented in Table 2.

\section{Overall survival}

Two studies reported overall survival at 5 years for all patients undergoing surgery (resection and laparotomy only), median $23 \%$ $(15-31 \%)$ (Table 3$)$. Studies in which it was unclear whether resections were R0 or R1/2, or only presented data for both types of resection combined, had a median 5-year survival of $32 \%$ (9$63 \%)$. Sixteen studies presented 5-year survival for patients undergoing R0 resection, either for the whole study population or for subgroups of patients. Median 5-year survival for these studies was $30 \%$ (range $15-67 \%$ ). Eleven studies reporting 5-year survival for nonradical resections had a median 5-year survival of $7.2 \%$ (range $0-30 \%$ ), and six studies reporting patients who did not undergo resection had a median 5 -year survival of $0 \%$ (range $0-6 \%)$. Survival according to study design is also presented in Table 3. Patients who underwent resection without any additional therapy had a median 5 -year survival of $30 \%$ (range $20-33.6 \%$ ), whereas patients who received additional therapy had a median 5year survival of $35.5 \%$ (range $9-63 \%$ ). Studies in which use of additional therapy was not stated reported 5-year survival between 14 and 58\% (median 32.5\%). Overall 5-year survival was not reported by three studies (Donato et al, 1994; Hohenberger et al, 1994; Cady et al, 1998), and one study reporting survival from 
Table 2 Morbidity (fatal and non-fatal)

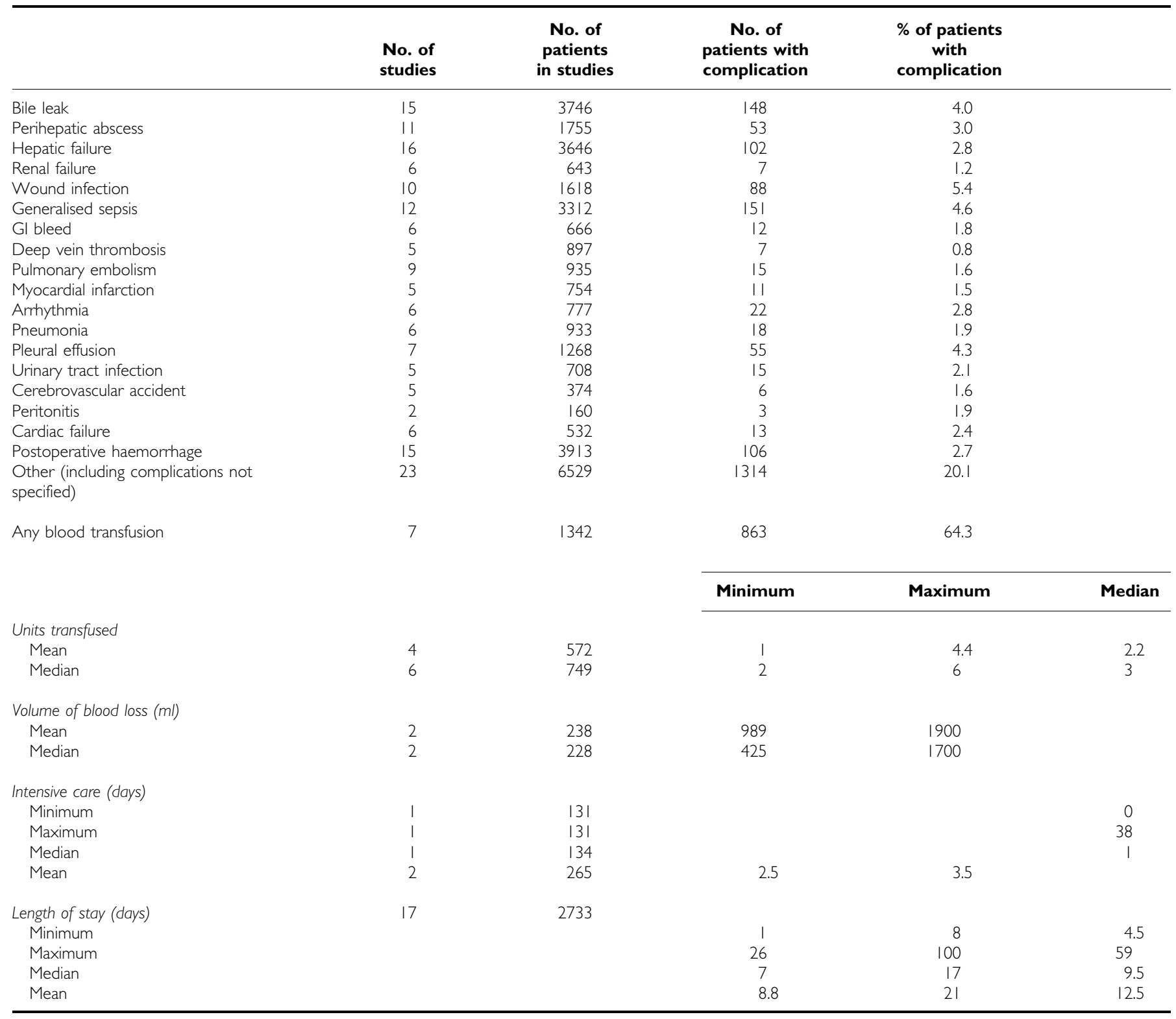

repeat hepatic resections only was not included in this analysis (Fernandez-Trigo et al, 1995).

\section{Disease-free survival}

Disease-free survival was reported by fewer studies. Median disease-free survival was 11.6 (Hohenberger et al, 1994) and 17 (Doci et al, 1995) months (median 14.3 months) for radically resected patients and between 10.8 and 37.4 months (median 17.2 months) for patients with unspecified resections (Jenkins et al, 1997; Ohlsson et al, 1998; Kemeny et al, 1999c; Minagawa et al, 2000).

Five-year disease-free survival was reported between 9 and $35 \%$ (median 18\%) (Doci et al, 1995; Scheele et al, 1996; Ambiru et al, 1999b) and 4-47\% (median 21\%) (Hughes et al, 1989; Jenkins et al, 1997; Ohlsson et al, 1998; Bradley et al, 1999; Iwatsuki et al, 1999; Minagawa et al, 2000; Okano et al, 2000) by studies with radically resected patients and unspecified resections, respectively.

\section{Sites of recurrence}

Sites of recurrence following hepatic resection were reported by 13 studies (Table 4). They were classified as liver, extrahepatic or liver plus extrahepatic. Twenty-two percent of all patients experienced recurrence in the liver only, although this is likely to be underestimated as two studies did not specify the proportion of liver-only recurrences. Liver plus extrahepatic recurrences and extrahepatic-only recurrences were experienced by 16 and $24 \%$ of patients, respectively. In addition, one study reported recurrences in $235(62.5 \%)$ radically resected patients, although sites of recurrence were not specified.

\section{Prognostic factors}

Many studies reported 1-year, 3-year, 5-year and median overall survival and disease-free survival for various potential prognostic factors relating to the characteristics of the primary tumour and/or liver metastases. In general, comparison between studies is limited 
Table 3 Overall 5-year survival

Radical (RO) resection

Nonradical resection

Patients not resected

Prospective studies

Resected (RO/RI unclear)

Radical

Non radical

Retrospective studies

Resected (RO/RI unclear)

Radical

Non radical

Single centre

Resected (RO/RI unclear)

Radical

Non radical

Multicentre
Resected (RO/RI unclear)
Radical

Non radical

Two centres

Resected (RO/RI unclear)

Radical

Resection only

Resection+additional therapy

Resection+use of additional therapy unclear
Fuhrman et al, 1995; Harms et al, 1999

Hughes et al, 1989; Beckurts et al, 1997; Jamison et al, 1997; Ohlsson et al, 1998; Bakalakos et al, 1998a; Bradley et al, 1999; Fong et al, 1999; Harmon et al, 1999; Harms et al, 1999; Iwatsuki et al, 1999; Kemeny et al, 1999a, c; Bolton and Fuhrman, 2000; Minagawa et al, 2000; Moroz et al, 2002) (Jenkins et al, 1997; Okano et al, 2000) (Savage and Malt, 1992: Rees et al, 1997: Scheele et al, 1996

Savage and Malt, 1992; Sugihara et al, 1993; Doci et al, 1995; Fuhrman et al, 1995; Steele Jr et al, 1995; Scheele et al, 1996; Beckurts et al, 1997; Jenkins et al, 1997; Rees et al, 1997; Riesener et al, 1998; Bakalakos et al, 1998a; Fong et al, 1999; Harms et al, 1999; Iwatsuki et al, 1999; Ambiru et al, 1999b; Okano et al, 2000

Lange et al, 1989; Savage and Malt, 1992; Sugihara et al, 1993; Steele Jr et al, 1995; Beckurts et al, 1997; Jenkins et al, 1997; Rees et al, 1997; Bakalakos et al, 1998a; Fong et al, 1999; Harms et al, 1999; Okano et al, 2000

Fuhrman et al, 1995; Steele Jr et al, 1995; Scheele et al, 1996; Bakalakos et al, 1998a; Harms et al, 1999; Moroz et al, 2002

Scheele et al, 1996; Beckurts et al, 1997; Rees et al, 1997; Ohlsson et al, 1998; Kemeny et al, 1999a, c

Steele Jr et al, 1995; Scheele et al, 1996; Beckurts et al, 1997; Rees et al, 1997

Steele Jr et al, 1995; Beckurts et al, 1997; Rees et al, 1997

Hughes et al, 1989; Savage and Malt, 1992; Jamison et al, 1997; Jenkins et al, 1997; Bakalakos et al, 1998a; Bradley et al, 1999; Fong et al, 1999; Harmon et al, 1999; Iwatsuki et al, 1999; Bolton and Fuhrman, 2000; Minagawa et al, 2000; Okano et al, 2000; Moroz et al, 2002 Savage and Malt, 1992; Doci et al, 1995; Fuhrman et al, 1995; Jenkins et al, 1997; Riesener et al, 1998; Bakalakos et al, 1998a; Fong et al, 1999; Harms et al, 1999; Iwatsuki et al, 1999; Ambiru et al, 1999b; Okano et $a l, 2000$

Savage and Malt, 1992; Jenkins et al, 1997; Bakalakos et al, 1998a; Fong et al, 1999; Harms et al, 1999; Iwatsuki et al, 1999; Okano et al, 2000

Jamison et al, 1997; Ohlsson et al, 1998; Bakalakos et al, 1998a; Harmon et al, 1999; Kemeny et al, 1999c; Bolton and Fuhrman, 2000; Moroz et al, 2002

Savage and Malt, 1992; Sugihara et al, 1993; Doci et al, 1995; Fuhrman et al, 1995; Scheele et al, 1996; Jenkins et al, 1997; Rees et al, 1997; Riesener et al, 1998; Bakalakos et al, 1998a; Fong et al, 1999; Harms et al, 1999; Iwatsuki et al, 1999; Ambiru et al, 1999b; Okano et al, 2000 Savage and Malt, 1992; Sugihara et al, 1993; Jenkins et al, 1997; Rees et al, 1997; Bakalakos et al, 1998a; Fong et al, 1999; Harms et al, 1999; Iwatsuki et al, 1999; Okano et al, 2000

Hughes et al, 1989; Kemeny et al, 1999a; Minagawa et al, 2000

Steele Jr et al, 1995

Steele Jr et al, 1995

Beckurts et al, 1997; Bradley et al, 1999

Beckurts et al, 1997

Ohlsson et al, 1998; Harms et al, 1999; Iwatsuki et al, 1999; Kemeny et al, 1999a; Ambiru et al, 1999b

Steele Ir et al, 1995; Jamison et al, 1997; Ohlsson et al, 1998; Riesener et al, 1998; Bakalakos et al, 1998a; Bradley et al, 1999; Fong et al, 1999; Harmon et al, 1999; Harms et al, 1999; Iwatsuki et al, 1999; Kemeny et al, 1999a; Ambiru et al, 1999b; Kemeny et al, 1999c; Bolton and Fuhrman, 2000

Hughes et al, 1989; Savage and Malt, 1992; Sugihara et al, 1993; Doci et al, 1995; Fuhrman et al, 1995; Scheele et al, 1996; Beckurts et al, 1997; Jenkins et al, 1997; Rees et al, 1997; Minagawa et al, 2000; Okano et al, 2000; Moroz et al, 2002 5-year survival (\%) 
Sites of recurrence

\begin{tabular}{|c|c|c|c|c|}
\hline & Patients & Liver (\%) & Extrahepatic (\%) & Liver+extra hepatic (\%) \\
\hline $\begin{array}{l}\text { Ambiru et al, 1999a, b } \\
(n=174)\end{array}$ & $\begin{array}{l}\text { Resection+HAl } \\
\text { Resection +PVI } \\
\text { Resection only } \\
\text { Total (R0 resection) }\end{array}$ & $\begin{array}{r}14(17.9) \\
5(16.7) \\
19(28.8) \\
38(21.8)\end{array}$ & $\begin{array}{l}16(20.5) \\
12(40) \\
20(30.3) \\
48(27.6)\end{array}$ & $\begin{aligned} 9 & (11.5) \\
7 & (23.3) \\
12 & (18.2) \\
28 & (16.1)\end{aligned}$ \\
\hline Bradley et al, $1999(n=134)$ & Resection RO/RI unclear & $36(26.9)$ & $27(20.1)$ & $21(15.7)$ \\
\hline Doci et al, $1995(n=224)$ & R0 resection & $73(32.6)$ & $57(25.4)$ & $25(\mid 1.2)$ \\
\hline $\begin{array}{l}\text { Donato et al, } 1994 \\
(n=102)\end{array}$ & $\begin{array}{l}\text { Resection only } \\
\text { Resection+chemo } \\
\text { Total (R0 resection) }\end{array}$ & $\begin{array}{l}21(33.9) \\
15(37.5) \\
36(35.3)\end{array}$ & $\begin{aligned} 5 & (8.1) \\
7 & (17.5) \\
12 & (11.8)\end{aligned}$ & \\
\hline $\begin{array}{l}\text { Kemeny et al, 1999a, b, c } \\
(n=77)\end{array}$ & $\begin{array}{l}\text { Resection only } \\
\text { Resection+chemo } \\
\text { Total (RO/RI unclear) }\end{array}$ & & & $\begin{aligned} 24 & (53.3) \\
8 & (25.0) \\
32 & (41.6)^{\mathrm{a}}\end{aligned}$ \\
\hline Minagawa et al, $2000(n=234)$ & RO/RI unclear & & $73(31.2)$ & $98(41.7)^{\mathrm{a}}$ \\
\hline Ohlsson et al, $1998(n=|| \mid)$ & RO/RI unclear & $19(17.1)$ & $19(17.1)$ & $43(38.7)$ \\
\hline Okano et al, $2000(n=152)$ & RO/RI unclear & $38(25.0)$ & $26(17.1)$ & $6(3.9)$ \\
\hline Rees et al, $1997(n=89)$ & R0 resection & $25(28.1)$ & $27(30.3)$ & $9(10.1)$ \\
\hline $\begin{array}{l}\text { Riesener et al, } 1998 \\
(n=109)\end{array}$ & $\begin{array}{l}\text { R0 resection } \\
\text { R0 resection+chemo } \\
\text { Total }\end{array}$ & $\begin{array}{l}18(30.5) \\
10(20.0) \\
28(25.7)\end{array}$ & $\begin{array}{r}13(22.0) \\
9(18.0) \\
22(20.2)\end{array}$ & $\begin{array}{l}15(25.4) \\
12(24.0) \\
27(24.8)\end{array}$ \\
\hline MSKCC, $1999(n=156)$ & $\begin{array}{l}\text { Resection+combined therapy } \\
\text { Resection+monotherapy } \\
\text { Total (RO/RI unclear) }\end{array}$ & $\begin{array}{cl}7 & (9.5) \\
30 & (36.6) \\
37 & (23.7)\end{array}$ & $\begin{array}{l}35(47.3) \\
44(51.8) \\
79(50.6)\end{array}$ & \\
\hline Steele et al, $1995(n=150)$ & All undergoing surgery & $28(18.7)$ & | | (7.3) & $4(2.7)$ \\
\hline Sugihara et al, $1993(n=109)$ & R0 resection & $34(31.2)$ & $30(27.5)$ & \\
\hline Total $n=|82|$ & & $392(21.5)$ & 431 (23.7) & $293(16.1)$ \\
\hline
\end{tabular}

aProportion of patients with recurrence in the liver only not specified.

owing to differences in categorisation of the prognostic factors. A definition of 'synchronous' is not given in most cases, but could mean hepatic resection within 1 month (Hughes et al, 1989), 3 months (Jamison et al, 1997; Rees et al, 1997) or 6 months (Donato et al, 1994) of primary surgery. Time interval between resection of the primary tumour and metastases has been classified into five different categories. Categories for number and size of liver metastases are also extremely varied, and reporting of the type of liver resection is inconsistent. Results from multivariate analysis, which identified prognostic factors independently associated with overall survival, are shown in Table 5. As the factors included in the model differed for each study these cannot be directly compared.

\section{Repeat resections}

In studies that reported this outcome, between 3.6 and $17 \%$ (median 9\%) of patients underwent repeat hepatic resection (Scheele et al, 1996; Rees et al, 1997; Ohlsson et al, 1998; Bakalakos et al, 1998a; Bradley et al, 1999; Iwatsuki et al, 1999; Ambiru et al, 1999b; Kemeny et al, 1999c; Minagawa et al, 2000). Three hepatic resections were performed on $0.9-4 \%$ (median $3.8 \%$ ) of patients (Ohlsson et al, 1998; Bakalakos et al, 1998a; Minagawa et al, 2000), and just $0.4 \%$ underwent four resections (Minagawa et al, 2000). The Repeat Hepatic Registry reported a series of 170 patients undergoing repeat resection, of which $4.7 \%$ underwent a third resection (Fernandez-Trigo et al, 1995). Median and 5-year overall survival from the date of second liver resection for the 170 patients was 34 months and $32 \%$, respectively.

\section{DISCUSSION}

Although the prognosis of metastatic colorectal cancer is poor with few patients surviving for 5 years or more (Stangl et al, 1994) longterm survival has been reported following surgical resection of isolated hepatic metastases (Fong and Salo, 1999; Geoghegan and Scheele, 1999). The nature of the published studies of surgical resection for colorectal liver metastases did not allow for a quantitative analysis to be performed and we have thus undertaken a qualitative systematic review to summarize the available evidence for the effectiveness of this intervention.

Surgical resection of hepatic metastases from colorectal cancer can be undertaken safely in the majority of patients. The median postoperative (30 day) mortality reported by 24 studies was only $2.8 \%(0-6.6 \%)$. There was patchy reporting of the causes of postoperative death, with the most frequent causes being hepatic failure, postoperative haemorrhage, and sepsis. It is likely that current surgical and anaesthetic practice is associated with perioperative mortalities nearer to $1 \%$ as demonstrated in a recent multicentre trial (Nordlinger et al, 2005). Operative morbidity was more difficult to quantify as many studies reported only fatal 
Table 5 Prognostic factors by multivariate analysis

\begin{tabular}{|c|c|}
\hline & Significant (improved prognosis) \\
\hline Age & - \\
\hline Female & Donato et al, 1994 \\
\hline Male & Hohenberger et al, 1994 \\
\hline \multicolumn{2}{|l|}{ Primary tumour } \\
\hline Site of primary tumour & - \\
\hline Low grade of primary tumour & Scheele et al, 1996 \\
\hline $\begin{array}{l}\text { No regional lymph node metastases of primary } \\
\text { tumour (Duke's stage } A \text { or } B \text { ) }\end{array}$ & $\begin{array}{l}\text { Doci et al, 1995; Fong et al, 1999; Minagawa et al, } \\
2000\end{array}$ \\
\hline
\end{tabular}

Liver tumour

Metachronous

Time interval from primary (months)

Size of liver metastases $(\mathrm{cm})$

Number of liver tumours

Absence of satellite metastases

Percent hepatic replacement (less involvement)

Unilobar distribution of liver tumour

Fewer hepatic segments involved

Low/moderate grade of liver tumour

Nodes at hepatoduodenal ligament not involved

Local invasion of hepatic disease absent

Vascular invasion absent

Intrahepatic bile duct invasion absent

Extrahepatic disease absent

Presence of fibrous pseudocapsule

Low preoperative CEA level (ng/ml)

Low postoperative CEA level $(\mathrm{ng} / \mathrm{ml})$

Increased resection margin

Ro resection

Type of hepatic surgery

No intraoperative blood transfusion

Year of resection more recent

Complex vs simple disease
Sugihara et al, 1993: Donato et al, 1994; Beckurts et al, 1997; Harms et al, 1999

Hohenberger et al, 1994

$>12$ (Fong et al, 1999)

$>30$ (Iwatsuki et al, 1999)

Bolton and Fuhrman, 2000

$<8 \mathrm{~cm}$ (Rees et al, 1997)

$<5 \mathrm{~cm}$ (Scheele et al, 1996; Fong et al, 1999;

Okano et al, 2000)

$<8$ (Moroz et al, 2002)

I (Fong et al, 1999; Minagawa et al, 2000)

$<3$ (Iwatsuki et al, 1999; Okano et al, 2000)

Scheele et al, 1996

Hohenberger et al, 1994; Doci et al, 1995

Iwatsuki et al, 1999

Bolton and Fuhrman, 2000

Ohlsson et al, 1998

Beckurts et al, 1997; Harms et al, 1999; Minagawa et al, 2000

Moroz et al, 2002

Okano et al, 2000

Ohlsson et al, 1998; Fong et al, 1999; Iwatsuki et al, 1999

Okano et al, 2000

Ohlsson et al, 1998

$<200$ (Fong et al, 1999)

(Hohenberger et al, 1994)

$>5 \mathrm{~mm}$ (Rees et al, 1997)

Ro (Fong et al, 1999; Harms et al, 1999; Iwatsuk

Anatomical (Scheele et al, 1996)

(Ohlsson et al, 1998)

1985-95 vs 1971-84 (Ohlsson et al, 1998)

(Kemeny et al, 1999c) et al, 1999; Okano et al, 2000)
Nonsignificant

Hohenberger et al, 1994; Moroz et al, 2002

Moroz et al, 2002

Sugihara et al, 1993; Hohenberger et al, 1994; Rees et al, 1997; Kemeny et al, 1999c; Moroz et al, 2002 Sugihara et al, 1993; Hohenberger et al, 1994; Beckurts et al, 1997: Rees et al, 1997: Harms et al, 1999

Sugihara et al, 1993; Hohenberger et al, 1994; Beckurts et al, 1997; Rees et al, 1997; Harms et al, 1999

Hohenberger et al, 1994; Rees et al, 1997; Okano et al 2000

$0-3$ vs $\geqslant 4$ (Minagawa et al, 2000)

$\leqslant 2$ vs $2.1-5$. vs $\geqslant 5 \mathrm{~cm}$ (Sugihara et al, 1993)

$<5$ vs $\geqslant 5 \mathrm{~cm}$ (Kemeny et al, 1999c)

Harms et al, 1999; Bolton and Fuhrman, 2000

I vs $2-4$ vs $\geqslant 5$ (Sugihara et al, 1993)

I vs 2-3 vs >3 (Hohenberger et al, 1994; Doci et al, 1995; Rees et al, 1997)

| vs $>$ | (Beckurts et al, 1997)

$\leqslant 7$ vs $>7$ (Moroz et al, 2002)

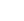

Sugihara et al, 1993; Hohenberger et al, 1994; Rees et al, 1997; Fong et al, 1999; Harms et al, 1999; Okano et al, 2000; Moroz et al, 2002

$-$

Okano et al, 2000

Okano et al, 2000

-

$\leqslant 5$ vs $5.1-30$ vs $\geqslant 30.1$ (Sugihara et al, 1993)

$<50$ vs $\geqslant 50$ (Minagawa et al, 2000)

$<5$ vs $>5$ (Hohenberger et al, 1994)

$\geqslant 1 \mathrm{~cm}$ vs $\leqslant 0.9 \mathrm{~cm}$ (Scheele et al, 1996)

(Sugihara et al, 1993; Doci et al, 1995; Bolton and Fuhrman, 2000)

-

Bolton and Fuhrman, 2000 morbidity or a very limited range of postoperative complications. It was therefore difficult to determine the proportion of patients experiencing operative morbidity and thus its overall impact on patients in the majority of studies. Some studies presented information on outcomes that may be surrogate markers for operative morbidity. Two studies reported information on the duration of stay in intensive care following surgery, the median time in one study was 1 day, while the mean from the two studies 
was 3 days. These limited results suggest that most patients require only a short period of intensive care following hepatic resection for colorectal metastases. The median or mean length of hospital stay reported by 17 studies ranged from 7-21 days indicating that while most patients made a rapid recovery following surgery, some experienced a more prolonged hospital stay possibly as a result of complications from their surgery. None of the studies included in this review presented information on recovery of patients' functional status or quality of life following discharge from hospital.

Two studies presented outcome data for all patients with isolated colorectal hepatic metastases who underwent surgery, resection and laparotomy only, with 15 and $31 \%$ of patients surviving 5 years, respectively (Fuhrman et al, 1995; Harms et al, 1999). Studies including only patients who underwent resection reported a survival of around $30 \%$ at 5 years for patients undergoing potentially 'curative' resection of isolated hepatic metastases and the majority are disease free at this time. The survival of patients undergoing R0 resections were substantially better (32\% at 5 years) than for patients undergoing R1 resections $(7.2 \%$ at 5 years $)$ and those who did not undergo resection $(0 \%$ at 5 years).

Patients undergoing surgery may have a better prognosis than other patients with metastatic colorectal cancer as their disease is both confined to the liver and circumscribed within it. The patients are also more likely to be of good performance status and have little or no comorbidity. Identifying a comparable control group in the absence of randomised trials is difficult. Goldberg et al (1998) identified 548 patients with recurrent colorectal cancer in a longitudinal study, of whom $222(41 \%)$ were thought to be suitable for 'curative intent' surgery. Potentially curative surgery was performed in $109(20 \%)$ and of these $28(5 \%)$ were performed for isolated liver metastases. The estimated recurrence-free survival of patients following liver resection was $32 \%$ at 5 years, similar to survival after lung resection and complete resection of local recurrence. The 5-year survival after curative surgery at other sites and multiple sites appeared worse (16 and $0 \%$, respectively). Although not stated, the survival of the patients not treated surgically or who had palliative surgery was by implication poor, but two out of 19 patients with circumscribed disease liver or lung disease treated nonsurgically were alive at final follow-up. A small number of retrospective studies have attempted to determine the natural history of patients with isolated liver metastases. In a review of 484 untreated patients with liver metastases from colorectal cancer, those with the best prognosis ( $\leqslant 25 \%$ liver involvement, primary tumour grade $1 / 2$, no extra hepatic tumour and no mesenteric nodal involvement), had a median survival of 21.3 months, compared with 30 months in patients undergoing hepatic resection in the same institution (Stangl et al, 1994). In a group of 125 patients with liver-only metastases, most of whom had had no therapy, the median survival was 12.5 months. All patients died within 5 years. Survival correlated with the extent of liver disease. The presence of three or fewer liver metastases was associated with a median survival of 24 months (Goslin et al, 1982). Lahr et al (1983) studied 175 untreated patients with liver metastases from colorectal cancer. The median survival of these patients was 6.1 months and the longest survivor lived for 67 months. Patients with 1-4 liver metastases lived longer than those with five or more metastases (median survival 11.8 vs 4 months) (Lahr et al, 1983). A study of 113 patients with hepatic metastases from colon cancer, reported a mean survival of 3 months in patients with widespread liver disease (Wood et al, 1976). Patients with metastases localised to a segment or lobe had a mean survival of 17 months, compared with 25 months for patients with a solitary liver metastases. The overall 1-year survival rates were 6,27 , and $60 \%$, respectively. Another study attempted to distinguish potentially resectable from unresectable disease (Wagner et al, 1984). Three groups of untreated patients were studied. Patients with solitary $(n=39)$, multiple unilateral $(n=31)$ and widespread $(n=182)$ had 3 -year survivals of 21, 6 and 4\%, respectively. However by 5 years virtually all were dead ( 3,0 and $2 \%$ survival, respectively). Some small studies have examined the outcome of patients with unresected synchronous hepatic metastases (Bengtsson et al, 1981; Boey et al, 1981; Finan et al, 1985; Gorog et al, 1997). The median survival of patients in these series ranged from 4.5 to 10.3 months. These studies suggest that there is a small select group of patients with isolated liver metastases from colorectal cancer who may live a long time without surgical intervention. However, their prognosis remains poor because of the inexorable hepatic progression and extrahepatic spread.

Disease recurrence is common after resection of colorectal hepatic metastases indicating that in the majority of cases the extent of the metastatic disease is underestimated by pre and intraoperative staging investigations. Around one-third of patients experienced disease recurrence in the liver alone and may be candidates for repeat resection. The remainder experienced recurrence concurrently in the liver and extrahepatic sites or in extrahepatic sites only. It may be that biological features in the tumour itself may be important as optimal imaging and this requires further study.

Identification of prognostic factors that predict the outcome following surgical resection of colorectal hepatic metastases would assist in the identification of those patients most likely to benefit from this intervention, or more importantly assist in the identification of patients who were unlikely to benefit. Comparison of the different studies included in this review was hampered by differing definitions of the prognostic factors considered for univariate or multivariate analyses. However, some potential prognostic factors were found to be significant in more than half of the studies. We are currently attempting to evaluate these potential prognostic factors using a large prospectively collected data set contributed by multiple centres. This will be published in due course.

This review was performed deliberately on series published up to the millennium as in recent years major changes have occurred in the management of colorectal liver metastases. These factors will almost certainly impact increasingly on the reported outcomes after 2000 (Poston et al, 2005). Firstly modern chemotherapy using cytotoxic agents alone offers extension of median survival to 2 years in patients with nonresectable disease (Cals et al, 2004; Goldberg et al, 2004; Grothey et al, 2004; Tournigand et al, 2004). When monoclonal biological agents are added to cytotoxic chemotherapy, the prospect of median survival now extends beyond 2 years, and $20 \%$ of patients will still be alive 4 years after detection of unresectable liver disease (Cunningham et al, 2004; Hurwitz et al, 2004; Saltz et al, 2004). It is therefore inevitable that the combination of surgical resection and chemotherapy, which is becoming commonplace, will impact on the survival in the surgical series. The EORTC EPOC trial which is the first to randomise liver resection patients to receive additional, modern, chemotherapy is due for reporting in 2007 (Nordlinger et al, 2005). Secondly, novel surgical strategies such as preoperative portal vein embolisation to increase residual acceptably safe volume, or two-stage hepatectomy to allow compensatory hepatic hyperplasia before completion of R0 resection (Abdalla et al, 2002; Pawlik et al, 2005; Poston et al, 2005), have also widened the number of resectable patients including those with extensive liveronly disease. These changes in the definition of resectability means that $>20 \%$ of patients with liver metastases can now be considered for surgery with curative intent at the outset. It is unclear what the long-term outcome of these strategies will be but the results appear encouraging (Abdalla et al, 2002; Pawlik et al, 2005; Poston et al, 2005). This present review should both set the standard for the reporting of subsequent surgical series and provide baseline results to which they may be compared. 
In summary there is a substantial body of evidence from prospective and retrospective case series summarised in this review demonstrating that resection of colorectal hepatic metastases can be performed safely with a low mortality rate and around one-third of patients will survive for 5 years or more. These outcomes in highly selected patients exceed those normally associated with metastatic colorectal cancer. Randomised trials comparing surgical resection with nonsurgical treatment are not now possible. Further information must come from well-documented prospective studies examining consecutive series of patients with colorectal cancer and randomised trials comparing liver resection alone with liver resection plus additional chemotherapy.

\section{ACKNOWLEDGEMENTS}

This work was funded by the NHS South East Research and Development Directorate. The views and opinions expressed herein are those of the authors and do not necessarily reflect those of the NHS Executive.

\section{REFERENCES}

Abdalla EK, Barnett CC, Doherty D, Curley SA, Vauthey JN (2002) Extended hepatectomy in patients with hepatobiliary malignancies with and without preoperative portal vein embolization. Arch Surg 137: 675680

Adam R, Akpinar E, Johann M, Kunstlinger F, Majno P, Bismuth H (1997) Place of cryosurgery in the treatment of malignant liver tumors. Ann Surg 225: 38-39

Ambiru S, Miyazaki M, Isono T, Ito H, Nakagawa K, Shimizu H, Kusashio K, Furuya S, Nakajima N (1999a) Hepatic resection for colorectal metastases: analysis of prognostic factors. Dis Colon Rectum 42: 632-639

Ambiru S, Miyazaki M, Ito H, Nakagawa K, Shimizu H, Nakajima N (1999b) Adjuvant regional chemotherapy after hepatic resection for colorectal metastases. Br J Surg 86: 1025-1031

Armstrong JG, Anderson LL, Harrison LB (1994) Treatment of liver metastases from colorectal cancer with radioactive implants. Cancer 73: $1800-1804$

Bakalakos EA, Kim JA, Young DC, Martin Jr EW (1998a) Determinants of survival following hepatic resection for metastatic colorectal cancer. World J Surg 22: $399-404$

Bakalakos EA, Young DC, Martin Jr EW (1998b) Radioimmunoguided surgery for patients with liver metastases secondary to colorectal cancer. Ann Surg Oncol 5: 590-594

Beckurts KT, Holscher AH, Thorban S, Bollschweiler E, Siewert JR (1997) Significance of lymph node involvement at the hepatic hilum in the resection of colorectal liver metastases. Br J Surg 84: 1081 - 1084

Bengtsson G, Carlsson G, Hafstrom L, Jonsson PE (1981) Natural history of patients with untreated liver metastases from colorectal cancer. Am J Surg 141: 586-589

Boey J, Choi TK, Wong J, Ong GB (1981) Carcinoma of the colon and rectum with liver involvement. Surg Gynecol Obstet 153: 864-868

Bolton JS, Fuhrman GM (2000) Survival after resection of multiple bilobar hepatic metastases from colorectal carcinoma. Ann Surg 231: 743-751

Bradley AL, Chapman WC, Wright JK, Marsh JW, Geevarghese S, Blair KT, Pinson CW (1999) Surgical experience with hepatic colorectal metastasis. Am Surg 65: $560-566$

Brand MI, Saclarides TJ, Dobson HD, Millikan KW (2000) Liver resection for colorectal cancer: liver metastases in the aged. Am Surg 66: $412-415$

Cady B, Jenkins RL, Steele Jr GD, Lewis WD, Stone MD, McDermott WV Jessup JM, Bothe A, Lalor P, Lovett EJ, Lavin P, Linehan DC (1998) Surgical margin in hepatic resection for colorectal metastasis: a critical and improvable determinant of outcome. Ann Surg 227: 566-571

Cals L, Rixe O, Francois E, Favre R, Merad L, Deplanque G, Laadem A, Juin P, Bereder JM, Bernardini D, Herait P (2004) Dose-finding study of weekly 24-h continuous infusion of 5-fluorouracil associated with alternating oxaliplatin or irinotecan in advanced colorectal cancer patients. Ann Oncol 15: 1018-1024

Cancer Research UK Information Resource Centre (2003) CancerStats. http//:info cancerresearchuk org/cancerstats

Cowley DE (1995) Prostheses for primary total hip replacement. A critical appraisal of the literature. Int J Technol Assess Health Care 11: $770-778$

Cunningham D, Humblet Y, Siena S, Khayat D, Bleiberg H, Santoro A, Bets D, Mueser M, Harstrick A, Verslype C, Chau I, Van CE (2004) Cetuximab monotherapy and cetuximab plus irinotecan in irinotecan-refractory metastatic colorectal cancer. N Engl J Med 351: 337-345

de Baere T., Elias D, Ducreux M, Dromain C, Kuach V, Gamal El Din M, Sobotka A, Lasser P, Roche A (1999) Percutaneous radiofrequency ablation of hepatic metastases. Preliminary experience. Gastroenterol Clin Biol 23: $1128-1133$

de Gramont A., Figer A, Seymour M, Homerin M, Hmissi A, Cassidy J, Boni C, Cortes-Funes H, Cervantes A, Freyer G, Papamichael D, Le Bail N., Louvet C, Hendler D, de Braud F., Wilson C, Morvan F, Bonetti A (2000) Leucovorin and fluorouracil with or without oxaliplatin as first-line treatment in advanced colorectal cancer. J Clin Oncol 18: 2938-2947

DeMatteo RP, Palese C, Jarnagin WR, Sun RL, Blumgart LH, Fong Y (2000) Anatomic segmental hepatic resection is superior to wedge resection as an oncologic operation for colorectal liver metastases. J Gastrointest Surg 4: $178-184$

Doci R, Bignami P, Montalto F, Gennari L (1995) Prognostic factors for survival and disease-free survival in hepatic metastases from colorectal cancer treated by resection. Tumori 81: $143-146$

Donato N, Dario C, Giovanni S, Virgilio B, Paolo DP, Roberto L, Gianfranco P, Mario L, Daniela P, Angelo T (1994) Retrospective study on adjuvant chemotherapy after surgical resection of colorectal cancer metastatic to the liver. Eur J Surg Oncol 20: 454-460

Donovan TB (1995) Interstitial treatment of colorectal metastases to the liver. Appl Radiol 24: 41-44

Douillard JY, Cunningham D, Roth AD, Navarro M, James RD, Karasek P, Jandik P, Iveson T, Carmichael J, Alakl M, Gruia G, Awad L, Rougier P (2000) Irinotecan combined with fluorouracil compared with fluorouracil alone as first-line treatment for metastatic colorectal cancer: a multicentre randomised trial. Lancet 355: $1041-1047$

Downs SH, Black N (1998) The feasibility of creating a checklist for the assessment of the methodological quality both of randomised and nonrandomised studies of health care interventions. J Epidemiol Community Health 52: 377-384

Fegiz G, Ramacciato G, Gennari L, Doci R, Pezzuoli G, Leggeri A, Peracchia A, Montorsi W, D'Angelo F, Aurello P (1991) Hepatic resections for colorectal metastases: the Italian multicenter experience. J Surg Oncol Suppl 2: $144-154$

Fernandez-Trigo V, Shamsa F, Sugarbaker PH (1995) Repeat liver resections from colorectal metastasis. Repeat Hepatic Metastases Registry. Surgery 117: 296-304

Figueras J, Valls C, Rafecas A, Fabregat J, Ramos E, Jaurrieta E (2001) Resection rate and effect of postoperative chemotherapy on survival after surgery for colorectal liver metastases. Br J Surg 88: 980 - 985

Finan PJ, Marshall RJ, Cooper EH, Giles GR (1985) Factors affecting survival in patients presenting with synchronous hepatic metastases from colorectal cancer: a clinical and computer analysis. Br J Surg 72: $373-377$

Fong Y, Blumgart LH, Fortner JG, Brennan MF (1995) Pancreatic or liver resection for malignancy is safe and effective for the elderly. Ann Surg 222: $426-434$

Fong Y, Cohen AM, Fortner JG, Enker WE, Turnbull AD, Coit DG, Marrero AM, Prasad M, Blumgart LH, Brennan MF (1997) Liver resection for colorectal metastases. J Clin Oncol 15: 938-946

Fong Y, Fortner J, Sun RL, Brennan MF, Blumgart LH (1999) Clinical score for predicting recurrence after hepatic resection for metastatic colorectal cancer: analysis of 1001 consecutive cases. Ann Surg 230: 309-318

Fong Y, Salo J (1999) Surgical therapy of hepatic colorectal metastasis. Semin Oncol 26: $514-523$

Fuhrman GM, Curley SA, Hohn DC, Roh MS (1995) Improved survival after resection of colorectal liver metastases. Ann Surg Oncol 2: 537-541 
Gayowski TJ, Iwatsuki S, Madariaga JR, Selby R, Todo S, Irish W, Starzl TE (1994) Experience in hepatic resection for metastatic colorectal cancer: analysis of clinical and pathologic risk factors. Surgery 116: $703-710$

Geoghegan JG, Scheele J (1999) Treatment of colorectal liver metastases. $\mathrm{Br}$ J Surg 86: $158-169$

Giacchetti S, Itzhaki M, Gruia G, Adam R, Zidani R, Kunstlinger F, Brienza S, Alafaci E, Bertheault-Cvitkovic F, Jasmin C, Reynes M, Bismuth H, Misset JL, Levi F (1999) Long-term survival of patients with unresectable colorectal cancer liver metastases following infusional chemotherapy with 5-fluorouracil, leucovorin, oxaliplatin and surgery. Ann Oncol 10: 663-669

Goldberg RM, Fleming TR, Tangen CM, Moertel CG, Macdonald JS, Haller DG, Laurie JA (1998) Surgery for recurrent colon cancer: strategies for identifying resectable recurrence and success rates after resection. Eastern Cooperative Oncology Group, the North Central Cancer Treatment Group, and the Southwest Oncology Group. Ann Intern Med 129: $27-35$

Goldberg RM, Sargent DJ, Morton RF, Fuchs CS, Ramanathan RK, Williamson SK, Findlay BP, Pitot HC, Alberts SR (2004) A randomized controlled trial of fluorouracil plus leucovorin, irinotecan, and oxaliplatin combinations in patients with previously untreated metastatic colorectal cancer. J Clin Oncol 22: 23-30

Gorog D, Toth A, Weltner J (1997) Prognosis of untreated liver metastasis from rectal cancer. Acta Chir Hung 36: 106-107

Goslin R, Steele Jr G, Zamcheck N, Mayer R, MacIntyre J (1982) Factors influencing survival in patients with hepatic metastases from adenocarcinoma of the colon or rectum. Dis Colon Rectum 25: 749-754

Grothey A, Sargent D, Goldberg RM, Schmoll HJ (2004) Survival of patients with advanced colorectal cancer improves with the availability of fluorouracil-leucovorin, irinotecan, and oxaliplatin in the course of treatment. J Clin Oncol 22: 1209-1214

Harmon KE, Ryan Jr JA, Biehl TR, Lee FT (1999) Benefits and safety of hepatic resection for colorectal metastases. Am J Surg 177: 402-404

Harms J, Obst T, Thorban S, Busch R, Fink U, Heidecke CD, Roder JD, Siewert JR (1999) The role of surgery in the treatment of liver metastases for colorectal cancer patients. Hepatogastroenterology 46: 2321-2328

Hohenberger P, Schlag P, Schwarz V, Herfarth C (1990) Tumor recurrence and options for further treatment after resection of liver metastases in patients with colorectal cancer. J Surg Oncol 44: 245-251

Hohenberger P, Schlag PM, Gerneth T, Herfarth C (1994) Pre- and postoperative carcinoembryonic antigen determinations in hepatic resection for colorectal metastases. Predictive value and implications for adjuvant treatment based on multivariate analysis. Ann Surg 219: $135-143$

Hugh TJ, Kinsella AR, Poston GJ (1997a) Management strategies for colorectal liver metastases - Part I. Surg Oncol 6: 19-30

Hugh TJ, Kinsella AR, Poston GJ (1997b) Management strategies for colorectal liver metastases - Part II. Surg Oncol 6: 31-48

Hughes K, Scheele J, Sugarbaker PH (1989) Surgery for colorectal cancer metastatic to the liver. Optimizing the results of treatment. Surg Clin North Am 69: 339-359

Hughes KS, Rosenstein RB, Songhorabodi S, Adson MA, Ilstrup DM, Fortner JG, Maclean BJ, Foster JH, Daly JM, Fitzherbert D (1988) Resection of the liver for colorectal carcinoma metastases. A multiinstitutional study of long-term survivors. Dis Colon Rectum 31: 1-4

Hurwitz H, Fehrenbacher L, Novotny W, Cartwright T, Hainsworth J, Heim W, Berlin J, Baron A, Griffing S, Holmgren E, Ferrara N, Fyfe G, Rogers B, Ross R, Kabbinavar F (2004) Bevacizumab plus irinotecan, fluorouracil, and leucovorin for metastatic colorectal cancer. $N$ Engl J Med 350: 2335-2342

Iwatsuki S, Dvorchik I, Madariaga JR, Marsh JW, Dodson F, Bonham AC, Geller DA, Gayowski TJ, Fung JJ, Starzl TE (1999) Hepatic resection for metastatic colorectal adenocarcinoma: a proposal of a prognostic scoring system. J Am Coll Surg 189: 291 - 299

Jamison RL, Donohue JH, Nagorney DM, Rosen CB, Harmsen WS, Ilstrup DM (1996) Hepatic resection for metastatic colorectal carcinoma results in the cure of some patients. Gastroenterology 110: A1394

Jamison RL, Donohue JH, Nagorney DM, Rosen CB, Harmsen WS, Ilstrup DM (1997) Hepatic resection for metastatic colorectal cancer results in cure for some patients. Arch Surg 132: 505-510

Jeffery GM, Hickey BE, Hider P (2002) Follow-up strategies for patients treated for non-metastatic colorectal cancer. The Cochrane Database of Systematic Reviews 2002, Issue 1. Art. No.: CD002200. DOI: 10.1002/ 14651858.CD002200
Jenkins LT, Millikan KW, Bines SD, Staren ED, Doolas A (1997) Hepatic resection for metastatic colorectal cancer. Am Surg 63: 605-610

Kemeny MM, Adak S, Gray B, Macdonald JS, Smith T, Lipsitz S, Sigurdson ER, O'Dwyer PJ, Benson III AB (2002) Combined-modality treatment for resectable metastatic colorectal carcinoma to the liver: surgical resection of hepatic metastases in combination with continuous infusion of chemotherapy - an intergroup study. J Clin Oncol 20: 1499-1505

Kemeny MM, Adak S, Lipsitz S, Gray B, MacDonald J, Benson II AB (1999a) Results of the Intergroup [Eastern Cooperative Oncology Group (ECOG) and Southwest Oncology Group (SWOG)] prospective randomized study of surgery alone versus continuous hepatic artery infusion of fudr and continuous systemic infusion of $5 \mathrm{fu}$ after hepatic resection for colorectal liver metastases. Proc Am Soc Clin Onc 18 (Meeting abstract 1012)

Kemeny N, Cohen A, Huang Y, Shi W, Blumgart L, Turnbull A, Sullivan D, Stockman J, Fong Y (1999b) Randomized study of hepatic arterial infusion (HAI) and systemic chemotherapy (SYS) versus sys alone as adjuvant therapy after resection of hepatic metastases from colorectal cancer. Proc Am Soc Clin Onc 18 (abstract 1011)

Kemeny N, Huang Y, Cohen AM, Shi W, Conti JA, Brennan MF, Bertino JR, Turnbull AD, Sullivan D, Stockman J, Blumgart LH, Fong Y (1999c) Hepatic arterial infusion of chemotherapy after resection of hepatic metastases from colorectal cancer. $N$ Engl J Med 341: $2039-2048$

Lahr CJ, Soong SJ, Cloud G, Smith JW, Urist MM, Balch CM (1983) A multifactorial analysis of prognostic factors in patients with liver metastases from colorectal carcinoma. J Clin Oncol 1: 720-726

Lange JF, Leese T, Castaing D, Bismuth H (1989) Repeat hepatectomy for recurrent malignant tumors of the liver. Surg Gynecol Obstet 169: $119-126$

Leslie KA, Rossi R, Hughes K, Tsao J (1995) Survival expectancy of patients alive 5 years after hepatic resection for metastatic colon carcinoma: report from the registry of hepatic metastases. Proc Am Soc Clin Onc 14 (abstract 477)

Lorenz M, Muller HH, Schramm H, Gassel HJ, Rau HG, Ridwelski K, Hauss J, Stieger R, Jauch KW, Bechstein WO, Encke A (1998) Randomized trial of surgery versus surgery followed by adjuvant hepatic arterial infusion with 5-fluorouracil and folinic acid for liver metastases of colorectal cancer. German Cooperative on Liver Metastases (Arbeitsgruppe Lebermetastasen). Ann Surg 228: $756-762$

Lorenz M, Staib-Sebler E, Koch B, Gog C, Waldeyer M, Encke A (1997) The value of postoperative hepatic arterial infusion following curative liver resection. Anticancer Res 17: 3825-3833

Minagawa M, Makuuchi M, Torzilli G, Takayama T, Kawasaki S, Kosuge T, Yamamoto J, Imamura H (2000) Extension of the frontiers of surgical indications in the treatment of liver metastases from colorectal cancer: long-term results. Ann Surg 231: 487-499

Minagawa M, Takayama T, Makuuchi M (1999) Late results justify resection for multiple and bilateralhepatic metastasis from colorectal cancer. Gastroenterology 116: G2043

Minton JP, Abou-Issa H (1990) Resection of hepatic metastases of colorectal carcinoma. Ohio Med 86: 191

Moroz P, Salama PR, Gray BN (2002) Resecting large numbers of hepatic colorectal metastases. ANZ J Surg 72: 5-10

Nadig DE, Wade TP, Fairchild RB, Virgo KS, Johnson FE (1997) Major hepatic resection. Indications and results in a national hospital system from 1988 to 1992. Arch Surg 132: 115-119

Nordlinger B, Jaeck D, Guiget M, Vaillant JC, Balladur P, Schaal JC (1992) Surgical resection of hepatic metastases: multicentric retrospective study by the French Association of Surgery. In Treatment of Hepatic Metastases of Colorectal Cancer, Nordlinger B, Jaeck D (eds), pp 129 - 161. Paris: Springer-Verlag

Nordlinger B, Sorbye H, Debois M, Praet M, Glimelius B, Poston GJ, Schlag PM, Walpole ET, Bechstein W, Gruenberger T (2005) Feasibility and risks of pre-operative chemotherapy (CT) with Folfox 4 and surgery for resectable colorectal cancer liver metastases (LM). Interim results of the EORTC Intergroup randomized phase III study 40983. Proc Am Soc Clin Oncol 23 (abstract 3528)

Nordlinger B, Vaillant JC, Guiguet M, Balladur P, Paris F, Bachellier P, Jaeck D (1994) Survival benefit of repeat liver resections for recurrent colorectal metastases: 143 cases. Association Francaise de Chirurgie. J Clin Oncol 12: 1491 - 1496

Ohlsson B, Stenram U, Tranberg KG (1998) Resection of colorectal liver metastases: 25-year experience. World J Surg 22: 268-276

Okano K, Yamamoto J, Kosuge T, Yamamoto S, Sakamoto M, Nakanishi Y, Hirohashi S (2000) Fibrous pseudocapsule of metastatic liver tumors 
from colorectal carcinoma. Clinicopathologic study of 152 first resection cases. Cancer 89: 267-275

Pawlik TM, Scoggins CR, Zorzi D, Abdalla EK, Andres A, Eng C, Curley SA, Loyer EM, Muratore A, Mentha G, Capussotti L, Vauthey JN (2005) Effect of surgical margin status on survival and site of recurrence after hepatic resection for colorectal metastases. Ann Surg 241: 715-722 (discussion)

Poston GJ, Adam R, Alberts S, Curley S, Figueras J, Haller D, Kunstlinger F, Mentha G, Nordlinger B, Patt Y, Primrose J, Roh M, Rougier P, Ruers T, Schmoll HJ, Valls C, Vauthey NJ, Cornelis M, Kahan JP (2005) OncoSurge: a strategy for improving resectability with curative intent in metastatic colorectal cancer. J Clin Oncol 23: 7125-7134

Primrose JN (2002) Treatment of colorectal metastases: surgery, cryotherapy, or radiofrequency ablation. Gut 50: $1-5$

Rees M, Plant G, Bygrave S (1997) Late results justify resection for multiple hepatic metastases from colorectal cancer. Br J Surg 84: 1136-1140

Riesener KP, Winkeltau G, Kasperk R, Cheng L, Schumpelick V (1998) Adjuvant regional arterial port chemotherapy after resection of colorectal liver metastases. Chirurg 69: 741-746

Rosen CB, Nagorney DM, Taswell HF, Helgeson SL, Ilstrup DM, van Heerden JA, Adson MA (1992) Perioperative blood transfusion and determinants of survival after liver resection for metastatic colorectal carcinoma. Ann Surg 216: 493-504

Rougier P, Milan C, Lazorthes F, Fourtanier G, Partensky C, Baumel H, Faivre J (1995) Prospective study of prognostic factors in patients with unresected hepatic metastases from colorectal cancer. Fondation Francaise de Cancerologie Digestive. Br J Surg 82: 1397-1400

Saltz LB, Cox JV, Blanke C, Rosen LS, Fehrenbacher L, Moore MJ, Maroun JA, Ackland SP, Locker PK, Pirotta N, Elfring GL, Miller LL (2000) Irinotecan plus fluorouracil and leucovorin for metastatic colorectal cancer. Irinotecan Study Group. N Engl J Med 343: $905-914$

Saltz LB, Meropol NJ, Loehrer Sr PJ, Needle MN, Kopit J, Mayer RJ (2004) Phase II trial of cetuximab in patients with refractory colorectal cancer that expresses the epidermal growth factor receptor. J Clin Oncol 22: 1201-1208

Savage AP, Malt RA (1992) Survival after hepatic resection for malignant tumours. Br J Surg 79: 1095-1101

Scheele J, Altendorf-Hofmann A, Stangl R, Schmidt K (1996) Surgical resection of colorectal liver metastases: Gold standard for solitary and radically resectable lesions. Swiss Surg, Suppl 4: 4-17

Scheele J, Stang R, Altendorf-Hofmann A, Paul M (1995) Resection of colorectal liver metastases. World J Surg 19: 59-71

Scheele J, Stangl R, Altendorf-Hofmann A (1990) Hepatic metastases from colorectal carcinoma: impact of surgical resection on the natural history. Br J Surg 77: $1241-1246$

Scheele J, Stangl R, Altendorf-Hofmann A, Gall FP (1991) Indicators of prognosis after hepatic resection for colorectal secondaries. Surgery 110: $13-29$
Seymour MT, Stenning SP, Cassidy J (1997) Attitudes and practice in the management of metastatic colorectal cancer in Britain. Colorectal Cancer Working Party of the UK Medical Research Council. Clin Oncol ( $R$ Coll Radiol) 9: $248-251$

Simmonds PC (2000) Palliative chemotherapy for advanced colorectal cancer: systematic review and meta-analysis. Colorectal Cancer Collaborative Group. BMJ 321: $531-535$

Stangl R, Altendorf-Hofmann A, Charnley RM, Scheele J (1994) Factors influencing the natural history of colorectal liver metastases. Lancet 343: $1405-1410$

Steele Jr G, Bleday R, Mayer RJ, Lindblad A, Petrelli N, Weaver D (1991) A prospective evaluation of hepatic resection for colorectal carcinoma metastases to the liver: Gastrointestinal Tumor Study Group Protocol 6584. J Clin Oncol 9: 1105-1112

Steele Jr G, Mayer R, Lindblad AA (1995) A prospective evaluation of hepatic resection for colorectal carcinoma metastases to the liver: followup report. J Hepatic Biliary Pancreatic Surg 2: 122-125

Sugihara K, Hojo K, Moriya Y, Yamasaki S, Kosuge T, Takayama T (1993) Pattern of recurrence after hepatic resection for colorectal metastases. $\mathrm{Br}$ J Surg 80: $1032-1035$

Taylor M, Forster J, Langer B, Taylor BR, Greig PD, Mahut C (1997) A study of prognostic factors for hepatic resection for colorectal metastases. Am J Surg 173: $467-471$

Tournigand C, Andre T, Achille E, Lledo G, Flesh M, Mery-Mignard D, Quinaux E, Couteau C, Buyse M, Ganem G, Landi B, Colin P, Louvet C, de GA (2004) FOLFIRI followed by FOLFOX6 or the reverse sequence in advanced colorectal cancer: a randomized GERCOR study. J Clin Oncol 22: $229-237$

van Ooijen B, Wiggers T, Meijer S, van der Heijde MN, Slooff MJ, van de Velde CJ, Obertop H, Gouma DJ, Bruggink ED, Lange JF (1992) Hepatic resections for colorectal metastases in The Netherlands. A multiinstitutional 10-year study. Cancer 70: 28-34

Wade TP, Virgo KS, Li MJ, Callander PW, Longo WE, Johnson FE (1996) Outcomes after detection of metastatic carcinoma of the colon and rectum in a national hospital system. J Am Coll Surg 182: 353-361

Wagner JS, Adson MA, van Heerden JA, Adson MH, Ilstrup DM (1984) The natural history of hepatic metastases from colorectal cancer. A comparison with resective treatment. Ann Surg 199: $502-508$

Weiss L, Grundmann E, Torhorst J, Hartveit F, Moberg I, Eder M, FenoglioPreiser CM, Napier J, Horne CH, Lopez MJ (1986) Haematogenous metastatic patterns in colonic carcinoma: an analysis of 1541 necropsies. J Pathol 150: 195-203

Wood CB, Gillis CR, Blumgart LH (1976) A retrospective study of the natural history of patients with liver metastases from colorectal cancer. Clin Oncol 2: 285-288

\section{Appendix A}

Tabulation of eligible studies is illustrated in Table A1.

\section{Appendix B}

Results of quality assessment in 39 studies are shown in Table A2. 
Table Al Tabulation of eligible studies

Overall survival

\begin{tabular}{|c|c|c|c|c|c|c|c|c|c|c|}
\hline \multirow[b]{2}{*}{$\begin{array}{l}\text { Study and } \\
\text { reference(s) }\end{array}$} & \multirow[b]{2}{*}{$\begin{array}{l}\text { Recruitment } \\
\text { period }\end{array}$} & \multirow[b]{2}{*}{ Study design } & \multirow[b]{2}{*}{$\begin{array}{l}\text { Selection of } \\
\text { patients }\end{array}$} & \multirow[b]{2}{*}{$\begin{array}{l}\text { Characteristics of } \\
\text { patients }\end{array}$} & \multirow[b]{2}{*}{ Subgroups } & \multirow[b]{2}{*}{$\begin{array}{l}\text { Postoperative } \\
\text { mortality }\end{array}$} & \\
\hline & & & & & & & $\begin{array}{l}\text { Median } \\
\text { (months) }\end{array}$ & I year (\%) & 3 year (\%) & 5 year $(\%)$ \\
\hline $\begin{array}{l}\text { Ambiru, } 1999 \\
\text { Japan } \\
\text { (Ambiru et al, } \\
\text { 1999a, b) }\end{array}$ & $1984-1998$ & $\begin{array}{l}\text { Retrospective } \\
\text { Single centre }\end{array}$ & $\begin{array}{l}\text { Patients } \\
\text { undergoing } \\
\text { radical (R0) } \\
\text { resection } \\
\text { only }\end{array}$ & $\begin{array}{l}n=174 \\
\text { Age range } 21-80 \text { years, } \\
\text { median } 63 \text { years } \\
\text { Men } 108 \text {, women } 66\end{array}$ & $\begin{array}{l}\text { (a) Total patients } 174 \\
\text { (b) HAI chemo } \\
\text { following resection } 78 \\
\text { (c) PVI chemo } \\
\text { following resection } 30 \\
\text { (d) Resection only } 66\end{array}$ & $\begin{array}{l}60 \text { days } \\
\text { (a) } 6 / 174(3.4 \%) \\
\text { (b) } 1 / 78(1.3 \%) \\
\text { (d) } 4 / 66(6.1 \%)\end{array}$ & $\begin{array}{l}\text { (b) }- \\
\text { (c) - } \\
\text { (d) - }\end{array}$ & $\begin{array}{l}83 \\
83 \\
65\end{array}$ & $\begin{array}{l}56 \\
25 \\
32\end{array}$ & $\begin{array}{l}40 \\
17 \\
20\end{array}$ \\
\hline $\begin{array}{l}\text { Bakalakos, } 1998 \\
\text { USA } \\
\text { (Bakalakos et al, } \\
\text { (998a, b) }\end{array}$ & $1978-1993$ & $\begin{array}{l}\text { Retrospective } \\
\text { Single centre }\end{array}$ & $\begin{array}{l}\text { All patients } \\
\text { undergoing } \\
\text { surgery }\end{array}$ & $\begin{array}{l}n=301 \\
\text { Age range } 25-83 \text { years, } \\
\text { median } 61 \text { years } \\
\text { Men } 144 \text {, women } 157\end{array}$ & $\begin{array}{l}\text { (a) Total } 301 \text { patients } \\
\text { (b) Resected group, } \\
\text { rendered free of gross } \\
\text { tumour } 238 \\
\text { (i) Histopathological } \\
\text { margins clear } 94 \\
\text { (ii) Histopathological } \\
\text { margins indeterminate }\end{array}$ & $\begin{array}{l}\text { Perioperative } \\
\text { (a) } 4 / 301 \text { ( } 1.3 \%)\end{array}$ & $\begin{array}{l}\text { (a) } 20.6 \\
\text { (b) } 23.2 \\
\text { (i) } 29.9 \\
\text { (ii) } 20.5 \\
\text { (iii) } 19.4 \\
\text { (c) } 13 \\
\text { (d) } 14.8\end{array}$ & $\begin{array}{l}-\overline{82} \\
88 \\
74 \\
76 \\
51 \\
68\end{array}$ & $\begin{array}{l}- \\
28 \\
40 \\
14 \\
26 \\
5 \\
9\end{array}$ & $\begin{array}{r}- \\
9 \\
20 \\
4 \\
6 \\
0 \\
0\end{array}$ \\
\hline
\end{tabular}

$\begin{array}{llll}\text { Beckurts, } 1997 \text { 1987-1994 Prospective Patients } n=126 & \text { (a) Total patients } 126\end{array}$

undergoing

Age range $38-80$ years,

resection median 61 years 47 , women 49

(Beckurts et al,

Bolton, $2000 \quad$ Up to $1999 \quad$ Retrospective

Patients $\quad n=165$

USA Single centre

undergoing
resection

Age range $25-90$ years,

(Bolton and

Fuhrman, 2000)

Men and women not

reported

margins indeterminate

74

margins involved 65
mistopathological

(c) Nonresected group,

underwent exploration

without resection

because of extent or

location of hepatic or

EH tumour 73

(d) Incomplete resection

group, had liver resections

but left with gross disease

in remaining liver or

(a) Total patients 126

119

\section{0 days}

(c) Nonradical

resection 7

(a) Total patients 165

Simple hepatic metastase ( $1-3$ metastatic lesions in a unilobar distribution

Within 30 days or 121

uring same hospita

Complex hepatic

(a) $10 / 165$ (6.1\%)

metastases ( $\geqslant 4$ distinc

(c) $4 / 44(4.7 \%)$

and separate lesions

within one lobe or at

least 2 distinct and

separate lesions in

opposite lobes) 44

$n=134$

Patients

Age range no

Two centres

undergoing
resection

reported,

Perioperative

$6 / 134(4.5 \%)$

Men 70, women 64

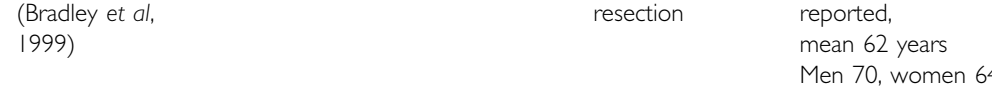


Table Al (Continued)

\begin{tabular}{|c|c|c|c|c|c|c|c|c|c|c|}
\hline \multirow[b]{2}{*}{$\begin{array}{l}\text { Study and } \\
\text { reference(s) }\end{array}$} & \multirow[b]{2}{*}{$\begin{array}{l}\text { Recruitment } \\
\text { period }\end{array}$} & \multirow[b]{2}{*}{ Study design } & \multirow[b]{2}{*}{$\begin{array}{l}\text { Selection of } \\
\text { patients }\end{array}$} & \multirow[b]{2}{*}{$\begin{array}{l}\text { Characteristics of } \\
\text { patients }\end{array}$} & \multirow[b]{2}{*}{ Subgroups } & \multirow[b]{2}{*}{$\begin{array}{l}\text { Postoperative } \\
\text { mortality }\end{array}$} & \multicolumn{4}{|c|}{ Overall survival } \\
\hline & & & & & & & $\begin{array}{l}\text { Median } \\
\text { (months) }\end{array}$ & I year $(\%)$ & 3 year $(\%)$ & 5 year $(\%)$ \\
\hline $\begin{array}{l}\text { Cady, } 1998 \\
\text { USA } \\
\text { (Cady et al, } \\
\text { 1998) }\end{array}$ & Up to 1996 & $\begin{array}{l}\text { Retrospective } \\
\text { Single centre }\end{array}$ & $\begin{array}{l}\text { Patients } \\
\text { undergoing } \\
\text { resection }\end{array}$ & $\begin{array}{l}n=253 \\
\text { Age not reported } \\
\text { Men and women not } \\
\text { reported }\end{array}$ & & $\begin{array}{l}30 \text { days } \\
9 / 253(3.6 \%)\end{array}$ & a & Disease-free sun & $\begin{array}{l}\text { al presented fo } \\
\text { only }\end{array}$ & rognostic factors \\
\hline $\begin{array}{l}\text { Doci, } 1995 \\
\text { Italy } \\
\text { (Doci et al, } \\
\text { 1995) }\end{array}$ & $1980-1993$ & $\begin{array}{l}\text { Unclear design } \\
\text { Single centre }\end{array}$ & $\begin{array}{l}\text { Patients } \\
\text { undergoing } \\
\text { radical (RO) } \\
\text { resection only }\end{array}$ & $\begin{array}{l}n=224 \\
\text { Age range and median } \\
\text { not reported } \\
\text { Men and women } \\
\text { not reported }\end{array}$ & & $\begin{array}{l}\text { From post surgical } \\
\text { complications } \\
5 / 224(2.2 \%)\end{array}$ & ${ }^{a}$ & 87 & 62 & 24 \\
\hline $\begin{array}{l}\text { Donato, } 1994 \\
\text { Italy } \\
\text { (Donato et al, } \\
\text { 1994) }\end{array}$ & $1977-1990$ & $\begin{array}{l}\text { Retrospective } \\
\text { Multicentre }\end{array}$ & $\begin{array}{l}\text { Patients } \\
\text { undergoing } \\
\text { radical (RO) } \\
\text { resection only }\end{array}$ & $\begin{array}{l}n=102 \\
\text { Age range } 35-84 \\
\text { years, median not } \\
\text { reported } \\
\text { Men } 56 \text {, women } 46\end{array}$ & $\begin{array}{l}\text { (a) Total patients } 102 \\
\text { (b) Post surgical treatment: } \\
\text { none } 62 \\
\text { (c) Post surgical treatment: } \\
\text { chemotherapy } 40\end{array}$ & Not reported & $\begin{array}{l}\text { (a) } 29 \\
\text { (b) } 25 \\
\text { (c) } 35\end{array}$ & $\begin{array}{l}88 \\
- \\
-\end{array}$ & $\begin{array}{l}36 \\
- \\
-\end{array}$ & $\begin{array}{l}- \\
- \\
-\end{array}$ \\
\hline $\begin{array}{l}\text { Fegiz, |99| } \\
\text { Italy } \\
\text { (Fegiz et al, } \\
\text { |99|) }\end{array}$ & Not reported & $\begin{array}{l}\text { Retrospective } \\
\text { Multicentre }\end{array}$ & $\begin{array}{l}\text { Patients } \\
\text { undergoing } \\
\text { resection }\end{array}$ & $\begin{array}{l}n=212 \\
\text { Age range and median } \\
\text { not reported } \\
\text { Men and women not } \\
\text { reported }\end{array}$ & & $\begin{array}{l}\text { I month } \\
|4 / 2| 2(6.6 \%)\end{array}$ & & & Not eligible & \\
\hline $\begin{array}{l}\text { Fernandez- } \\
\text { Trigo, I995 } \\
\text { USA, Norway, } \\
\text { Netherlands, } \\
\text { Sweden, } \\
\text { Germany, } \\
\text { France, Italy, } \\
\text { Spain } \\
\text { (Fernandez- } \\
\text { Trigo et al, } \\
\text { 1995) }\end{array}$ & Not reported & $\begin{array}{l}\text { Retrospective } \\
\text { Multicentre }\end{array}$ & $\begin{array}{l}\text { Patients } \\
\text { undergoing } \\
\text { repeat hepatic } \\
\text { resection }\end{array}$ & $\begin{array}{l}n=170 \\
\text { Age range } 28-84 \text { years, } \\
\text { Mean } 58 \text { years } \\
\text { Men and women } \\
\text { not reported }\end{array}$ & & Not reported & $\begin{array}{l}34 \\
\text { From second } \\
\text { resection }\end{array}$ & - & 45 & 32 \\
\hline $\begin{array}{l}\text { Figueras, 200I } \\
\text { Spain } \\
\text { (Figueras et al, } \\
\text { 200I) }\end{array}$ & $|99|-1998$ & $\begin{array}{l}\text { Prospective } \\
\text { Single centre }\end{array}$ & $\begin{array}{l}\text { Patients } \\
\text { undergoing } \\
\text { resection }\end{array}$ & $\begin{array}{l}n=150 \\
\text { Age range not reported, } \\
\text { mean } 60 \text { years }\end{array}$ & & $\begin{array}{l}30 \text { days } \\
7 / 150\end{array}$ & & & Not eligible & \\
\hline $\begin{array}{l}\text { Fong, } 1999 \\
\text { USA } \\
\text { (Fong et al, } \\
\text { 1995, 1997, } \\
\text { 1999; DeMatteo } \\
\text { et al, 2000) }\end{array}$ & $1985-1998$ & $\begin{array}{l}\text { Retrospective } \\
\text { Single centre }\end{array}$ & $\begin{array}{l}\text { Patients } \\
\text { undergoing } \\
\text { resection }\end{array}$ & $\begin{array}{l}n=1001 \\
\text { Age range } 27-87 \text { years, } \\
\text { median } 61 \text { years } \\
\text { Men } 581 \text {, women } 420\end{array}$ & $\begin{array}{l}\text { (a) Total patients } 1001 \\
\text { (b) Radical resection } \\
895 \\
\text { (c) Nonradical resection } \\
106\end{array}$ & $\begin{array}{l}30 \text { days } \\
28 / 100 \mid(2.8 \%)\end{array}$ & $\begin{array}{l}\text { (a) } 42 \\
\text { (b) } 53 \\
\text { (c) } 23\end{array}$ & $\begin{array}{l}89 \\
- \\
-\end{array}$ & $\begin{array}{l}57 \\
- \\
-\end{array}$ & $\begin{array}{l}37 \\
37 \\
20\end{array}$ \\
\hline $\begin{array}{l}\text { Fuhrman, } 1995 \\
\text { USA } \\
\text { (Fuhrman et al, } \\
\text { 1995) }\end{array}$ & $1988-1992$ & $\begin{array}{l}\text { Retrospective } \\
\text { Single centre }\end{array}$ & $\begin{array}{l}\text { All patients } \\
\text { undergoing } \\
\text { surgery }\end{array}$ & $\begin{array}{l}n=|5| \\
\text { Age range not reported, } \\
\text { median } 58.2 \text { years } \\
\text { Men } 69, \text { women } 82\end{array}$ & $\begin{array}{l}\text { (a) Satisfied pre-op criteria } \\
151 \\
\text { (b) Radical resection } 107 \\
\text { (c) Excluded from } \\
\text { resection } 44\end{array}$ & $\begin{array}{l}30 \text { days } \\
\text { a) } 3 / 107(2.8 \%)\end{array}$ & $\begin{array}{l}\text { (a) }- \\
\text { (b) - } \\
\text { (c) - }\end{array}$ & $\begin{array}{l}80 \\
90 \\
58\end{array}$ & $\begin{array}{r}40 \\
55 \\
5\end{array}$ & $\begin{array}{r}31 \\
44 \\
0\end{array}$ \\
\hline $\begin{array}{l}\text { Harmon, } 1999 \\
\text { USA } \\
\text { (Harmon et al, } \\
\text { 1999) }\end{array}$ & $1978-1998$ & $\begin{array}{l}\text { Retrospective } \\
\text { Single centre }\end{array}$ & $\begin{array}{l}\text { Patients } \\
\text { undergoing } \\
\text { resection }\end{array}$ & $\begin{array}{l}n=110 \\
\text { Age range } 41-90 \text { years, } \\
\text { mean } 63 \text { years } \\
\text { Men } 65 \text {, women } 45\end{array}$ & & $\begin{array}{l}30 \text { days } \\
5 / 110(4.5 \%)\end{array}$ & 42 & - & - & 46 \\
\hline
\end{tabular}


Table Al (Continued)

\begin{tabular}{|c|c|c|c|c|c|c|c|c|c|c|}
\hline \multirow[b]{2}{*}{$\begin{array}{l}\text { Study and } \\
\text { reference(s) }\end{array}$} & \multirow[b]{2}{*}{$\begin{array}{l}\text { Recruitment } \\
\text { period }\end{array}$} & \multirow[b]{2}{*}{ Study design } & \multirow[b]{2}{*}{$\begin{array}{l}\text { Selection of } \\
\text { patients }\end{array}$} & \multirow[b]{2}{*}{$\begin{array}{l}\text { Characteristics of } \\
\text { patients }\end{array}$} & \multirow[b]{2}{*}{ Subgroups } & \multirow[b]{2}{*}{$\begin{array}{l}\text { Postoperative } \\
\text { mortality }\end{array}$} & \multicolumn{4}{|c|}{ Overall survival } \\
\hline & & & & & & & $\begin{array}{l}\text { Median } \\
\text { (months) }\end{array}$ & I year (\%) & 3 year (\%) & 5 year (\%) \\
\hline $\begin{array}{l}\text { Harms, } 1999 \\
\text { Germany } \\
\text { (Harms et al, } \\
\text { 1999) }\end{array}$ & $1987-1998$ & $\begin{array}{l}\text { Retrospective } \\
\text { Single centre }\end{array}$ & $\begin{array}{l}\text { All patients } \\
\text { presenting with } \\
\text { colorectal liver } \\
\text { metastases }\end{array}$ & $\begin{array}{l}n=449 \\
\text { Age range } 25-87 \text { years, } \\
\text { median } 61.3 \text { years } \\
\text { Men 253, women } 196\end{array}$ & $\begin{array}{l}\text { (a) Total } 449 \text { patients } \\
\text { (b) Resection } 245 \\
\text { (i) Resection only } 86 \\
\text { (ii) Resection+regional } \\
\text { chemo } 54 \\
\text { (iii) Resection+systemic } \\
\text { chemo } 105 \\
\text { (iv) Radical resection } 225 \\
\text { (v) Nonradical resection } \\
20 \\
\text { (c) No resection } 204 \\
\text { (i) No treatment } 50\end{array}$ & $\begin{array}{l}30 \text { day } \\
\text { b) } 4 / 245 \text { (1.6\%) }\end{array}$ & $\begin{array}{l}\text { (a) } 25 \\
\text { (b) } 35 \\
\text { (i) - } \\
\text { (ii) - } \\
\text { (iii) }- \\
\text { (iv) } 64 \\
\text { (v) } 25 \\
\text { (c) } 16 \\
\text { (i) } 11\end{array}$ & $\begin{array}{l}78 \\
92 \\
91 \\
82 \\
95 \\
98 \\
70 \\
66 \\
-\end{array}$ & $\begin{array}{l}25 \\
38 \\
35 \\
35 \\
45 \\
45 \\
18 \\
15 \\
-\end{array}$ & $\begin{array}{r}15 \\
30 \\
30 \\
17 \\
35 \\
30 \\
11 \\
2 \\
-\end{array}$ \\
\hline $\begin{array}{l}\text { Hohenberger, } \\
1994 \\
\text { Germany } \\
\text { (Hohenberger } \\
\text { et al, 1990, } \\
\text { 1994) }\end{array}$ & $|98|-199 \mid$ & $\begin{array}{l}\text { Prospective } \\
\text { Single centre }\end{array}$ & $\begin{array}{l}\text { Patients } \\
\text { undergoing } \\
\text { radical (RO) } \\
\text { resection only }\end{array}$ & $\begin{array}{l}n=|4| \\
\text { Age range } 30-79 \text { years, } \\
\text { median } 59 \text { years } \\
\text { Men } 99, \text { women } 67\end{array}$ & & $\begin{array}{l}\text { Post op } \\
6 / 166 \text { (3.6\%) }\end{array}$ & $\begin{array}{l}\mathrm{a} \\
30\end{array}$ & - & - & \\
\hline $\begin{array}{l}\text { Hughes, } 1989 \\
\text { USA, Germany, } \\
\text { England } \\
\text { (Hughes et al, } \\
\text { 1988, 1989; } \\
\text { Leslie et al, } \\
\text { 1995) }\end{array}$ & $1948-1985$ & $\begin{array}{l}\text { Retrospective } \\
\text { Multicentre }\end{array}$ & $\begin{array}{l}\text { Patients } \\
\text { undergoing } \\
\text { resection }\end{array}$ & $\begin{array}{l}n=862 \\
\text { Age range and median } \\
\text { not reported } \\
\text { Men } 418 \text {, women } 327\end{array}$ & $\begin{array}{l}\text { (a) Metastatic disease } \\
\text { isolated to liver } 800 \\
\text { (b) Metastatic disease in } \\
\text { liver+hepatic/coeliac } \\
\text { nodes } 25 \\
\text { (c) Simultaneous resection } \\
\text { of extra hepatic } \\
\text { metastases } 37\end{array}$ & Not reported & $\begin{array}{l}(\mathrm{a})^{\mathrm{a}} \\
(\mathrm{b})^{\mathrm{a}} \\
(\mathrm{c})^{\mathrm{a}}\end{array}$ & & & $\begin{array}{r}32 \\
4 \\
20\end{array}$ \\
\hline $\begin{array}{l}\text { Iwatsuki, } 1999 \\
\text { USA } \\
\text { (Gayowski et al, } \\
\text { 1994; Iwatsuki } \\
\text { et al, 1999) }\end{array}$ & $1981-1996$ & $\begin{array}{l}\text { Retrospective } \\
\text { Single centre }\end{array}$ & $\begin{array}{l}\text { Patients } \\
\text { undergoing } \\
\text { resection }\end{array}$ & $\begin{array}{l}n=305 \\
\text { Age range } 26-82 \text { years, } \\
\text { mean } 60 \text { years } \\
\text { Men } 178 \text {, women } 127\end{array}$ & $\begin{array}{l}\text { (a) All patients undergoing } \\
\text { resection } \\
\text { (b) Resection margin } \\
>1 \mathrm{~cm} \\
\text { (c) Resection margin } \\
\leqslant 1 \mathrm{~cm} \\
\text { (d) Resection margin } \\
\text { involved }\end{array}$ & $\begin{array}{l}30 \text { days } \\
0 / 305(0 \%) \\
(3 \text { deaths within } 90 \\
\text { days) }\end{array}$ & $\begin{array}{l}\text { (a) - } \\
\text { (b) - } \\
\text { (c) } \\
\text { (d) }\end{array}$ & $\frac{94}{-}$ & $\begin{array}{r}47 \\
54.2 \\
48.4 \\
20.9\end{array}$ & $\begin{array}{r}32.3 \\
38.4 \\
31.4 \\
8.4\end{array}$ \\
\hline $\begin{array}{l}\text { Jamison, } 1997 \\
\text { USA } \\
\text { (Rosen et al, } \\
\text { 1992; Jamison } \\
\text { et al, 1996, } \\
\text { 1997) }\end{array}$ & $1960-1987$ & $\begin{array}{l}\text { Retrospective } \\
\text { Single centre }\end{array}$ & $\begin{array}{l}\text { Patients } \\
\text { undergoing } \\
\text { resection }\end{array}$ & $\begin{array}{l}n=280 \\
\text { Age range not reported, } \\
\text { mean } 59 \text { years } \\
\text { Men } 173 \text {, women } 107\end{array}$ & & $\begin{array}{l}30 \text { days } \\
5 / 280 \text { ( } 1.8 \%) \\
(10 \text { died within } 60 \\
\text { days) }\end{array}$ & $\begin{array}{c}n=269 \\
32.4\end{array}$ & 84 & 46 & 27 \\
\hline $\begin{array}{l}\text { Jenkins, } 1997 \\
\text { USA } \\
\text { (Jenkins et al, } \\
\text { 1997; Brand } \\
\text { et al, 2000) }\end{array}$ & $1975-1993$ & $\begin{array}{l}\text { Retrospective } \\
\text { Single centre }\end{array}$ & $\begin{array}{l}\text { Patients } \\
\text { undergoing } \\
\text { resection }\end{array}$ & $\begin{array}{l}n=|3| \\
\text { Age range } 30-88 \text { years, } \\
\text { mean } 62 \text { years } \\
\text { Men } 72 \text {, women } 59\end{array}$ & $\begin{array}{l}\text { (a) Total patients 131 } \\
\text { (b) Radical resection } \\
107 \\
\text { (c) Positive margins } 14 \\
\text { (d) Extra hepatic } \\
\text { disease } 10\end{array}$ & $\begin{array}{l}\text { In-hospital mortality } \\
\text { a) } 5 / 131(3.8 \%) \\
6 / 167(3.6 \%)\end{array}$ & $\begin{array}{l}\text { (a) } 33 \\
\text { (b) } 36 \\
\text { (c) } 21 \\
\text { (d) } 18\end{array}$ & $\begin{array}{l}- \\
- \\
-\end{array}$ & $\begin{array}{l}42 \\
50 \\
11 \\
29\end{array}$ & $\begin{array}{r}25 \\
30 \\
0 \\
0\end{array}$ \\
\hline $\begin{array}{l}\text { Kemeny, } 1999 \\
\text { USA (abstract) }\end{array}$ & Not reported & $\begin{array}{l}\text { Prospective } \\
\text { Multicentre }\end{array}$ & $\begin{array}{l}\text { Patients } \\
\text { undergoing } \\
\text { resection }\end{array}$ & $\begin{array}{l}n=109 \\
\text { Age not reported }\end{array}$ & $\begin{array}{l}\text { (a) Total patients } \\
109 \\
\text { (b) Resection only } 56\end{array}$ & $\begin{array}{l}\text { Operative death } \\
\text { a) } 2 / 109(2.6 \%)\end{array}$ & $\begin{array}{l}\text { (b) } 47.5 \\
\text { (c) } 34.2\end{array}$ & 91 & 66 & 32 \\
\hline
\end{tabular}


Table Al (Continued)

Overall survival

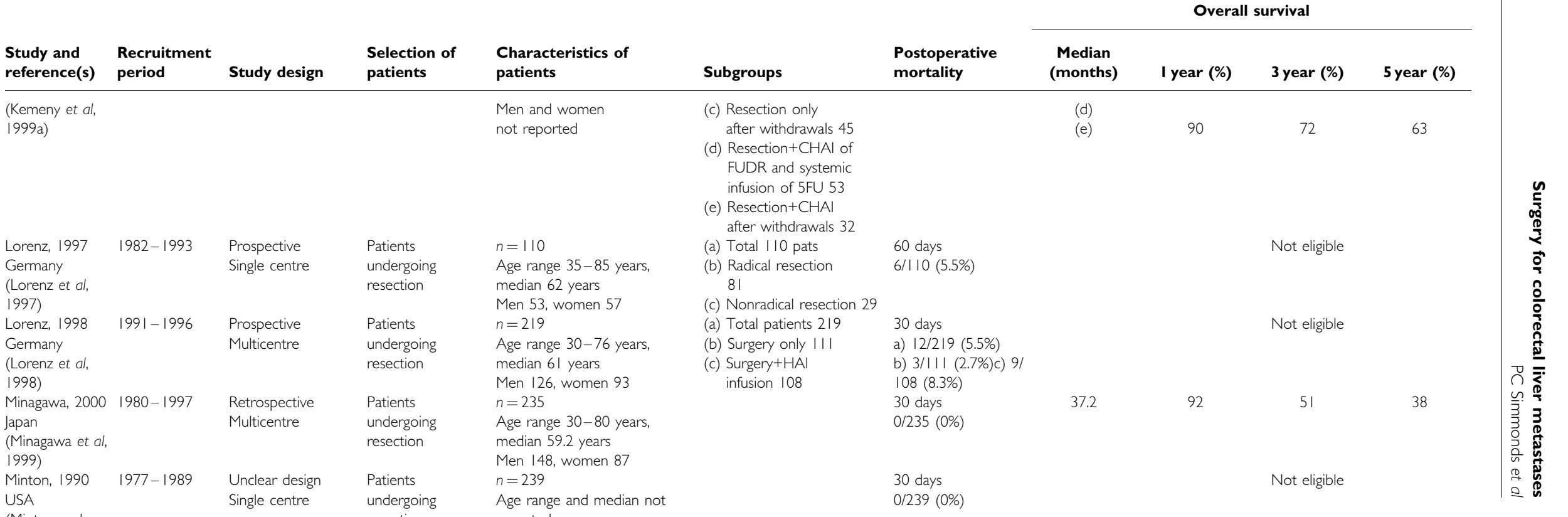

\begin{tabular}{|c|c|c|c|c|}
\hline $\begin{array}{l}\text { MSKCC, } 1999 \\
\text { USA } \\
\text { (Kemeny et al, } \\
\text { 1999b, c) }\end{array}$ & Not reported & $\begin{array}{l}\text { Prospective } \\
\text { Single centre }\end{array}$ & $\begin{array}{l}\text { Patients } \\
\text { undergoing } \\
\text { resection }\end{array}$ & $\begin{array}{l}n=156 \\
\text { Age range } 28-79 \text { years } \\
\text { median } 59 \text { years } \\
\text { Men } 91 \text {, women } 65\end{array}$ \\
\hline $\begin{array}{l}\text { Nadig, } 1997 \\
\text { USA } \\
\text { (Nadig et al, } \\
\text { 1997) }\end{array}$ & $1987-1992$ & $\begin{array}{l}\text { Retrospective } \\
\text { Multicentre }\end{array}$ & $\begin{array}{l}\text { Patients } \\
\text { undergoing } \\
\text { resection }\end{array}$ & $\begin{array}{l}n=275 \\
\text { Age not reported } \\
\text { Men and women not } \\
\text { reported }\end{array}$ \\
\hline $\begin{array}{l}\text { Nordlinger, } \\
1992 \\
\text { France } \\
\text { (Nordlinger } \\
\text { et al, 1992) }\end{array}$ & $|959-199|$ & $\begin{array}{l}\text { Retrospective } \\
\text { Multicentre }\end{array}$ & $\begin{array}{l}\text { Patients } \\
\text { undergoing } \\
\text { resection }\end{array}$ & $\begin{array}{l}n=1818 \\
\text { Age range not reported } \\
\text { mean } 60 \text { years } \\
\text { Men } 1041 \text {, women } \\
777\end{array}$ \\
\hline
\end{tabular}

(a) 123 patients

curative resection

(b) 36 consecutive

patients treated with

selective internal

radiation

therapy+hepatic

arterial chemotherapy.

More advanced disease, not

Total 156 pats

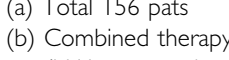
( $\mathrm{HAl}+$ systemic chemotherapy) 74

(c) Monotherapy (systemic chemotherapy) 82

30 days

a) $1 / 123(0.8 \%)$

(a) 38

(b) 16

88

53

Died before starting

chemo

(a) $5 / 156(3.2 \%)$

(b) 72.2

(c) 59.3

30 days

| |/275 (4\%)

30 days

$43 / 1818$ (2.4\%)
Not eligible

Not eligible 
Table Al (Continued)

\begin{tabular}{|c|c|c|c|c|c|c|c|c|c|c|}
\hline \multirow[b]{2}{*}{$\begin{array}{l}\text { Study and } \\
\text { reference(s) }\end{array}$} & \multirow[b]{2}{*}{$\begin{array}{l}\text { Recruitment } \\
\text { period }\end{array}$} & \multirow[b]{2}{*}{ Study design } & \multirow[b]{2}{*}{$\begin{array}{l}\text { Selection of } \\
\text { patients }\end{array}$} & \multirow[b]{2}{*}{$\begin{array}{l}\text { Characteristics of } \\
\text { patients }\end{array}$} & \multirow[b]{2}{*}{ Subgroups } & \multirow[b]{2}{*}{$\begin{array}{l}\text { Postoperative } \\
\text { mortality }\end{array}$} & \multicolumn{4}{|c|}{ Overall survival } \\
\hline & & & & & & & $\begin{array}{l}\text { Median } \\
\text { (months) }\end{array}$ & I year (\%) & 3 year $(\%)$ & 5 year $(\%)$ \\
\hline $\begin{array}{l}\text { Ohlsson, } 1998 \\
\text { Sweden } \\
\text { (Ohlsson et al, } \\
\text { 1998) }\end{array}$ & $197 \mid-1995$ & $\begin{array}{l}\text { Prospective } \\
\text { Single centre }\end{array}$ & $\begin{array}{l}\text { Patients } \\
\text { undergoing } \\
\text { resection }\end{array}$ & $\begin{array}{l}n=111 \\
\text { Age not reported } \\
\text { Men } 60, \text { women } 51\end{array}$ & $\begin{array}{l}\text { (a) Total patients III } \\
\text { (b) Operative } \\
\text { mortality excluded } \\
107 \\
\text { (c) } 1971-198468 \\
\text { (d) } 1985-199543\end{array}$ & $\begin{array}{l}30 \text { days } \\
\text { (a) } 4 / 111 \text { ( } 3.6 \%) \\
\text { (c) } 4 / 68(5.9 \%) \\
\text { d) } 0 / 43(0 \%)\end{array}$ & $\begin{array}{l}\text { (a) } 25.2 \\
\text { (b) }{ }^{\mathrm{a}}- \\
\text { (c) } 21.6 \\
\text { (d) })^{\mathrm{a}} 40.8\end{array}$ & $\begin{array}{l}- \\
- \\
-\end{array}$ & $\begin{array}{l}37 \\
- \\
- \\
-\end{array}$ & $\begin{array}{l}25 \\
\frac{25}{35}\end{array}$ \\
\hline $\begin{array}{l}\text { Okano, } 2000 \\
\text { Japan } \\
\text { (Okano et al, } \\
\text { 2000) }\end{array}$ & $1992-1996$ & $\begin{array}{l}\text { Retrospective } \\
\text { Single centre }\end{array}$ & $\begin{array}{l}\text { Patients } \\
\text { undergoing } \\
\text { resection }\end{array}$ & $\begin{array}{l}n=152 \\
\text { Age range } 35-87 \text { years, } \\
\text { mean } 59.5 \text { years } \\
\text { Men 104, women } 48\end{array}$ & $\begin{array}{l}\text { (a) Total } 152 \text { patients } \\
\text { (b) Thick fibrous } \\
\text { pseudocapsule (10 } \\
\text { or more bundles) } 47 \\
\text { (c) Thin fibrous } \\
\text { pseudocapsule } \\
\text { (several layers of collagen } \\
\text { bundles } \\
\text { in histologic } \\
\text { sections) } 46 \\
\text { (d) No fibrous pseudo } \\
\text { capsule } 59 \\
\text { (e) Radical resection } \\
\text { I21 } \\
\text { (f) RI resection } 21 \\
\text { (g) R2 resection } 10\end{array}$ & $\begin{array}{l}\text { Within I month } \\
\text { after surgery } \\
\text { a) 0/152 (0\%) }\end{array}$ & $\begin{array}{l}\text { (a) - } \\
\text { (b) - } \\
\text { (c) - } \\
\text { (d) - } \\
\text { (e) } \\
\text { (f) } \\
\text { (g) }\end{array}$ & $\begin{array}{r}91 \\
100 \\
93 \\
86 \\
96 \\
71 \\
80\end{array}$ & $\begin{array}{l}65 \\
88 \\
71 \\
41 \\
71 \\
44 \\
38\end{array}$ & $\begin{array}{l}58 \\
88 \\
64 \\
31 \\
67 \\
30 \\
25\end{array}$ \\
\hline $\begin{array}{l}\text { Rees, } 1997 \\
\text { UK } \\
\text { (Rees et al, } \\
\text { 1997) }\end{array}$ & $1986-1996$ & $\begin{array}{l}\text { Prospective } \\
\text { Single centre }\end{array}$ & $\begin{array}{l}\text { Patients } \\
\text { undergoing } \\
\text { resection }\end{array}$ & $\begin{array}{l}n=107 \\
\text { Age not reported } \\
\text { Men and women } \\
\text { not reported }\end{array}$ & $\begin{array}{l}\text { (a) Total group } 107 \\
\text { (b) Radical resection } \\
89 \\
\text { (c) Nonradical resection } 18\end{array}$ & $\begin{array}{l}30 \text { days } \\
\text { (a) } 1 / 107(0.9 \%)\end{array}$ & $\begin{array}{l}\text { (a) - } \\
\text { (b) - } \\
\text { (c) - }\end{array}$ & $\begin{array}{l}87 \\
94 \\
56\end{array}$ & $\begin{array}{l}47 \\
56 \\
11\end{array}$ & $\begin{array}{r}30 \\
37 \\
6\end{array}$ \\
\hline $\begin{array}{l}\text { Riesener, } 1998 \\
\text { Germany } \\
\text { (Riesener et al, } \\
\text { 1998) }\end{array}$ & $1986-1995$ & $\begin{array}{l}\text { Retrospective } \\
\text { Single centre }\end{array}$ & $\begin{array}{l}\text { Patients } \\
\text { undergoing } \\
\text { radical (RO) } \\
\text { resection only }\end{array}$ & $\begin{array}{l}N=109 \\
\text { Age range } 23-83 \text { years, } \\
\text { mean } 62 \text { years } \\
\text { Men } 64 \text {, Women } 45\end{array}$ & $\begin{array}{l}\text { (a) Total patients } \\
109 \\
\text { (b) Resection only } \\
59 \\
\text { (c) Resection+ } \\
\text { chemotherapy } 50\end{array}$ & $\begin{array}{l}\text { In-hospital } \\
\text { a) 5/109 (4.6\%) }\end{array}$ & $\begin{array}{l}\text { (b) - } \\
\text { (c) - }\end{array}$ & $\overline{-}$ & - & $\begin{array}{l}24 \\
21\end{array}$ \\
\hline $\begin{array}{l}\text { Savage, } 1992 \\
\text { USA } \\
\text { (Savage and } \\
\text { Malt, 1992) }\end{array}$ & $1962-1988$ & $\begin{array}{l}\text { Retrospective } \\
\text { Single centre }\end{array}$ & $\begin{array}{l}\text { Patients } \\
\text { undergoing } \\
\text { resection }\end{array}$ & $\begin{array}{l}n=104 \\
\text { Age range } 28-79 \text { years, } \\
\text { mean } 60.1 \text { years } \\
\text { Men } 53, \text { women } 51\end{array}$ & $\begin{array}{l}\text { (a) Total patients } \\
104 \\
\text { (b) Radical resection } \\
76 \\
\text { (c) Nonradical } \\
\text { resection } 28\end{array}$ & Not reported & $\begin{array}{l}\text { (a) } 25 \\
\text { (b) } 30 \\
\text { (c) } 21\end{array}$ & $\begin{array}{l}76 \\
80 \\
66\end{array}$ & $\begin{array}{l}36 \\
42 \\
17\end{array}$ & $\begin{array}{r}18 \\
23 \\
0\end{array}$ \\
\hline $\begin{array}{l}\text { Scheele, } 1996 \\
\text { Germany } \\
\text { (Scheele et al, } \\
\text { 1990, 1991, } \\
\text { 1995, 1996; } \\
\text { Stangl et al, } \\
\text { 1994) }\end{array}$ & $1960-1993$ & $\begin{array}{l}\text { Prospective } \\
\text { Single Centre }\end{array}$ & $\begin{array}{l}\text { All patients } \\
\text { presenting with } \\
\text { colorectal liver } \\
\text { metastases }\end{array}$ & $\begin{array}{l}n=1751 \\
\text { Age range } 26-91 \text { years, } \\
\text { median } 59 \text { years } \\
\text { Men } 258 \text {, women } 215\end{array}$ & $\begin{array}{l}\text { (a) Total patients } \\
1715 \\
\text { (b) Total resections } \\
498 \\
\text { (c) Palliative debulking } \\
35 \\
\text { (d) Curative intent } 463 \\
\text { (e) Radical resection } 394 \\
\text { (i) Radical resection } \\
\text { excluding operative } \\
\text { mortality } 376 \\
\text { (f) Non radical resection } 69\end{array}$ & $\begin{array}{l}30 \text { days } \\
\text { (b) } 25 / 498(5.0 \%) \\
\text { (c) } 3 / 35(8.6 \%) \\
\text { (e) } 18 / 394(4.6 \%) \\
\text { (f) } 4 / 69(5.8 \%)\end{array}$ & $\begin{array}{l}\text { (c) } 16 \\
\text { (d) }- \\
(\mathrm{e})- \\
(\mathrm{i}) \mathrm{a} \\
(\mathrm{f}) \\
\left(\mathrm{f}^{\mathrm{a}} 14.8\right. \\
\text { (g) } 7.4 \\
(\mathrm{~h})^{\mathrm{a}} 16.3\end{array}$ & $\begin{array}{l}- \\
- \\
- \\
- \\
-\end{array}$ & $\begin{array}{l}\overline{46} \\
52 \\
55 \\
- \\
- \\
-\end{array}$ & $\begin{array}{r}0 \\
33 \\
38 \\
39 \\
- \\
0 \\
5\end{array}$ \\
\hline
\end{tabular}


Table Al (Continued)

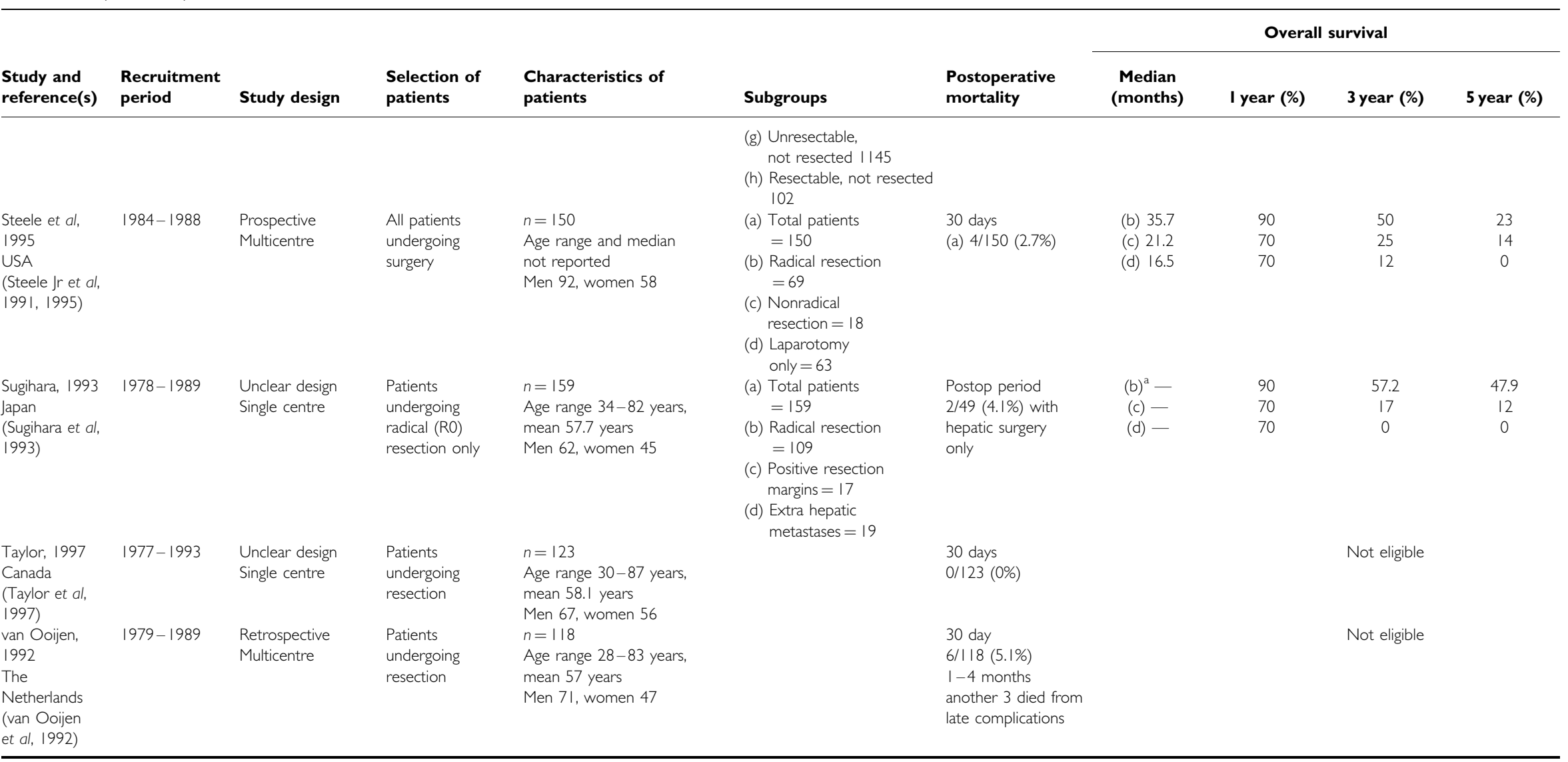


Surgery for colorectal liver metastases

PC Simmonds et al

Table A2 Results of quality assessment in 39 studies

No. of studies with response (\%)

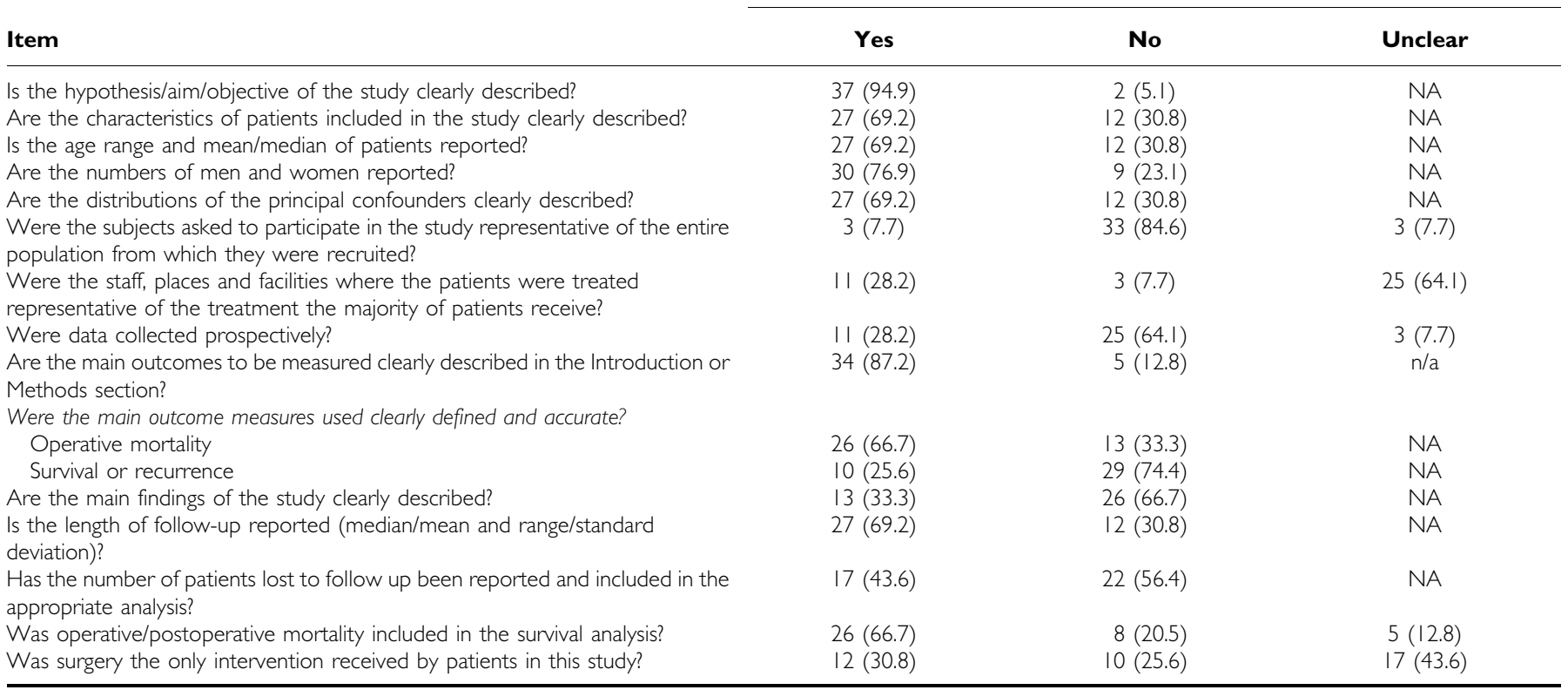

